\title{
Electro-oxidation of ethylene glycol and glycerol at palladium-decorated FeCo@Fe core-shell nanocatalysts for alkaline direct alcohol fuel cells: functionalized MWCNT supports and impact on product selectivity
}

Omobosede O. Fashedemi ${ }^{\mathrm{a}}$, Hamish A. Miller ${ }^{\mathrm{b}}$, Andrea Marchionni ${ }^{\mathrm{b}}$, Francesco Vizza $*^{\mathrm{b}}$ and Kenneth I. Ozoemena $*^{\mathrm{ac}}$

${ }^{a}$ Department of Chemistry, University of Pretoria, Pretoria 0002, South Africa. E-mail:

kozoemena@csir.co.za; Fax: +27 128412135; Tel: +27 128413664

${ }^{\mathrm{b}}$ Istituto di Chimica dei Composti Organometallici, Consiglio Nazionale delle Ricerche (ICCOM-CNR), via Madonna del Piano 10, 50019 Sesto Fiorentino, Italy. E-mail: francesco.vizza@iccom.cnr.it; Fax: +39 0555225203; Tel: +39 0555225286, 0555225239

${ }^{\mathrm{c}}$ Energy Materials, Materials Science and Manufacturing, Council for Scientific \& Industrial Research (CSIR), Pretoria 0001, South Africa

Half-cell reactions and alkaline direct ethylene glycol and glycerol fuel cells (DEGFC and DGFC) have been studied on Pd-based ternary core-shell (FeCo@Fe@Pd) nanocatalyst using multi-walled carbon nanotubes bearing carboxylic (MWCNT-COOH) and sulfonic acid (MWCNT-SO ${ }_{3} \mathrm{H}$ ) as supporting platforms. The core-shell-shell nature of this nanocatalyst, obtained via the "microwave-induced top-down nanostructuring and decoration", was clearly proven from atomic resolution transmission electron microscopy (ARTEM). The functional groups of the MWCNTs show a huge impact on the physicochemical properties of the FeCo@Fe@Pd nanocatalyst towards the electrocatalytic oxidation of EG and GLY in alkaline media.The FeCo@ $\mathrm{Fe} @ \mathrm{Pd}$ on - $\mathrm{COOH}$-treated MWCNTs showed the small particle size of ca. $7.4 \mathrm{~nm}$, uniform loading of the catalyst on the support, large electrochemically-active surface area and enhanced electrocatalytic activity compared to the $\mathrm{FeCo} @ \mathrm{Fe} @ \mathrm{Pd}$ on $-\mathrm{SO}_{3} \mathrm{H}$-bearing MWCNTs. As a preliminary test, FeCo@Fe@Pd/MWCNT-COOH was used for passive, air-breathing anion-exchange membrane based fuel cells (AEM-DEGFC and AEM-DGFC). The analysis of the exhaust products, established using NMR spectroscopy, revealed a high selectivity towards the complete oxidation of both EG and GLY under benign experimental conditions.

\section{Introduction}

Alkaline direct alcohol fuel cells (ADAFCs) are very attractive renewable and clean energy devices for portable electronics, e-mobility and stationary applications. Ethylene glycol (EG) is a fairly new type of liquid feed in the development of fuel cells, ${ }^{1-3}$ but it is considered as the most viable alternative to methanol. EG has become very attractive because of its high theoretical charge capacity $\left(4.8 \mathrm{Ah} \mathrm{mL}^{-1}\right)$, high boiling point, and high efficiency of electric power conversion. ${ }^{4-6}$ Interestingly, some recent studies have revealed that $\mathrm{EG}$ can be directly produced from catalytic conversion of biomass-related cellulose with high yields, which can provide new opportunities for sustainable widespread commercial applications of direct ethylene glycol fuel (DEGFCs). ${ }^{7,8}$ 
Another important alternative alcohol to methanol and ethanol based fuel cells is glycerol (GLY) due to its low-cost, simple purification and storage, non-volatility and environment-friendliness, non-toxicity, bio-renewability, a charge capacity of $5.13 \mathrm{Ah}$ $\mathrm{mL}^{-1}$ and high volumetric energy density of $6.4 \mathrm{kWh} \mathrm{L}^{-1} \cdot 9,10$ Unlike the bio-methanol and bio-ethanol, which are obtained from the fermentation process of biomass, the biomassderived GLY is mostly obtained as a waste by-product in the production of biodiesel via a trans-esterification reaction. ${ }^{11}$ Today, the realisation of low-cost alkaline direct glycerol fuel cells (DGFCs) are more promising than ever before as biodiesel-derived GLY can be obtained at a relatively lower market price compared to methanol and ethanol.

Platinum-based catalysts remain the state-of-the-art anodic materials for DEGFCs and DGFCs. ${ }^{6,12}$ But the use of Pt catalysts will limit the widespread commercialization of these fuel cell devices due to the inherent scarcity and high-cost of Pt. Palladium (Pd)based catalysts are attracting major attention as the most viable materials for ADAFCs. ${ }^{13-}$ ${ }^{16}$ The interest in $\mathrm{Pd}$ stems from its natural abundance and low-cost compared to $\mathrm{Pt}(\mathrm{Pd}$ currently sells at half the price of $\mathrm{Pt}),{ }^{17-23}$ and enhanced electrochemical kinetics in alkaline media and ADAFCs than Pt catalysts.

Although both EG and GLY meet the criteria for efficient fuels (such as high boiling point for use at temperatures $(\mathrm{T})>100{ }^{\circ} \mathrm{C}$ at near-ambient pressure, commercially available and low-cost) they are still fraught with the problem of incomplete electrooxidation to $\mathrm{CO}_{2}$ (carbonates in alkaline media) ${ }^{6,24}$ due to the strong $\mathrm{C}-\mathrm{C}$ bond that cannot be easily cleaved. ${ }^{25}$ Therefore, in order to increase the efficiency of fuel utilization, active catalysts, having sufficient ability to break $\mathrm{C}-\mathrm{C}$ bond in ethylene glycol, are strongly required. In fact, it is now consensual that glycerol suffers partial oxidation $^{26-28}$ generating glyceraldehyde, glycerate, mesoxalate, dihydroxyacetone and hydroxypyruvate, among other substances, leading to loss of energetic efficiency. It is difficult for Pd to break the $\mathrm{C}-\mathrm{C}$ bond, ${ }^{29,30}$ hence the need to dilute it with other metals (alloys) as co-catalysts ${ }^{31,32}$ to promote the scission of $\mathrm{C}-\mathrm{C}$ bonds. The dilution of $\mathrm{Pd}$ with base metals has the dual advantage of further reducing the cost of catalysts and improving the electrocatalytic activities. Recently, we introduced Pd-based ternary core-shell with a bimetallic $(\mathrm{FeCo})$ core supported on commercial Vulcan carbon XC-72 (i.e., $\mathrm{FeCo} @ \mathrm{Fe} @ \mathrm{Pd} / \mathrm{C}$ ) via "microwave-induced top-down nanostructuring and decoration" (MITNAD) strategy. ${ }^{33-35}$ The MITNAD strategy is simply the adoption of fast microwave irradiation for a one-step top-down nanosizing of large-sized soft magnetic FeCo@Fe/C core-shell material (0.21-1.5 microns) to sub-10 nm sized Pd-coated structure, FeCo@Fe@Pd/C. In the present work, we have interrogated the use of two differently chemically-functionalized multi-walled carbon nanotubes (MWCNTs) bearing mainly the $-\mathrm{COOH}$ or $-\mathrm{SO}_{3} \mathrm{H}$ surface groups (abbreviated herein as $\mathrm{MWCNT}-\mathrm{COOH}$ and MWCNT-SO${ }_{3} \mathrm{H}$, respectively), as supporting platforms for the FeCo@Fe@Pd catalyst. We clearly prove that the functional groups have a huge impact on the physicochemical properties of the FeCo@Fe@Pd catalyst towards the electrocatalytic oxidation of EG and GLY. Preliminary tests for passive, air-breathing anion-exchange membrane based fuel cells (AEM-DEGFC and AEM-DGFC) with FeCo@ Fe@Pd/MWCNT-COOH revealed a high selectivity towards the complete oxidation of both EG and GLY under benign experimental conditions. 


\section{Experimental}

\section{Materials}

Multi-walled carbon nanotubes ( $\geq 95 \%$ as MWCNT, O.D $\times$ I.D $\times$ length, $7-15 \mathrm{~nm} \times 3-6$ $\mathrm{nm} \times 0.5-200 \mu \mathrm{m}$ ), absolute ethanol, ethylene glycol (extra pure), glycerol (extra pure), acetic anhydride (ACS reagent grade), Nafion perfluorinated ion-exchange resin (5 wt $\%$ in mixture of lower aliphatic alcohols), iron(II) chloride tetrahydrate, $\left(\mathrm{FeCl}_{2} \cdot 4 \mathrm{H}_{2} \mathrm{O}\right)$, cobalt(II) chloride hexahydrate $\left(\mathrm{CoCl}_{2} \cdot 6 \mathrm{H}_{2} \mathrm{O}\right)$, and palladium(II) chloride $\left(\mathrm{PdCl}_{2}\right)$ and polyvinylpyrolidone (PVP) were obtained from Sigma-Aldrich. Pure nitrogen was supplied by Air Liquide (Pty) Ltd (South Africa). Ultrapure water (resistivity: 18.2 M $\Omega$ $\mathrm{cm}$ ) was obtained from a Milli-Q water system (Millipore Corp., Bedford, MA, USA). All other common analytical grade reagents were used as received from the suppliers without further purification.

The as-received MWCNTs were purified and subjected surface-functionalized (mainly $\mathrm{COOH}$ surface groups) using the conventional acid-treatment strategy. ${ }^{36}$ Briefly, the asreceived MWCNTs were first treated with $2.6 \mathrm{M} \mathrm{HNO}_{3}$ by refluxing for $24 \mathrm{~h}$, following by treatment with concentrated $\mathrm{H}_{2} \mathrm{SO}_{4} / \mathrm{HNO}_{3}$ mixture $(3: 1$ ratio) for $24 \mathrm{~h}$, and subsequently stirring for about $30 \mathrm{~min}$ in a $\mathrm{H}_{2} \mathrm{SO}_{4} / \mathrm{H}_{2} \mathrm{O}_{2}$ mixture $\left(4: 1\right.$ ratio) at $70^{\circ} \mathrm{C}$. The acid-functionalised MWCNT was washed with copious amount of ultrapure water, and finally oven-dried at $110{ }^{\circ} \mathrm{C}$ to obtain a solid black product (abbreviated herein as MWCNT-COOH). IR [(KBr) $\left.v_{\max } / \mathrm{cm}^{-1}\right]$ ]: $3428(\mathrm{OH})$ str, 1710 and $1572(\mathrm{C}=\mathrm{O})$ str, 1210 $(\mathrm{OH})$ bend, $1048(\mathrm{C}=\mathrm{O})$ str. The MWCNT- $\mathrm{COOH}$ was sulfonated using literatureestablished method. ${ }^{37,38}$ Briefly, $120 \mathrm{mg}$ of MWCNT-COOH was mixed with $20 \mathrm{~mL}$ $\mathrm{H}_{2} \mathrm{SO}_{4}$ and $300 \mathrm{~mL}$ of acetic anhydride and stirred at $70{ }^{\circ} \mathrm{C}$ for $2 \mathrm{~h}$, and allowed to cool to room temperature under continuous stirring. The material was repeatedly washed with ultrapure water and oven-dried at $70{ }^{\circ} \mathrm{C}$ to yield a black solid product (abbreviated herein as MWCNT-SO $\left.{ }_{3} \mathrm{H}\right)$. IR $\left[(\mathrm{KBr}) v_{\max } / \mathrm{cm}^{-1}\right]: 2969,2848(\mathrm{C}-\mathrm{H})$ str, 1466 and $1377(\mathrm{O}=\mathrm{S}=$ O)str.

\section{Preparation of FeCo@Fe@Pd/MWCNT nanocatalysts}

The Pd-based core-shell nanocatalysts were prepared following our recently reported procedure that used Vulcan XC-72 carbon support. ${ }^{33-35}$ In the present study, MWCNT$\mathrm{COOH}$ and MWCNT-SO $\mathrm{S}_{3} \mathrm{H}$ are used as supports rather than the Vulcan XC-72. First, FeCo@Fe/MWCNT-COOH and FeCo@Fe/MWCNT-SO 3 H core-shell nanoalloys were obtained by a simple reduction method via hydrogenation. Briefly, a mixture of $\mathrm{FeCl}_{2} \cdot 4 \mathrm{H}_{2} \mathrm{O}(0.5302 \mathrm{mg}, 2.67 \mathrm{mmol})$ and $\mathrm{CoCl}_{2} \cdot 6 \mathrm{H}_{2} \mathrm{O}(0.3650 \mathrm{mg}, 1.53 \mathrm{mmol})$ were dissolved in $20 \mathrm{~mL}$ of deionised water containing $0.15 \mathrm{~g}$ of MWCNT-COOH or MWCNT- $\mathrm{SO}_{3} \mathrm{H}$. The suspension was ultrasonicated for about $30 \mathrm{~min}$, and then heated under continuous magnetic stirring until the solvent was completely evaporated to give smooth, thick slurry. The slurry was oven-dried at $60{ }^{\circ} \mathrm{C}$, and then ground in an agate mortar to give a fine dark and free-flowing powder. The $\mathrm{FeCo} / \mathrm{MWCNT}-\mathrm{COOH}$ or $\mathrm{FeCo} / \mathrm{MWCNT}-\mathrm{SO}_{3} \mathrm{H}$ powder was heated in a tube furnace at $300{ }^{\circ} \mathrm{C}$ under flowing $\mathrm{H}_{2} / \mathrm{Ar}$ for $2 \mathrm{~h}$, and then annealed at $500{ }^{\circ} \mathrm{C}$ for $2 \mathrm{~h}$ and then cooled to room temperature 
under Ar atmosphere to give the core-shell alloy structure (FeCo@ Fe/MWCNT-COOH or FeCo@ $\left.\mathrm{Fe} / \mathrm{MWCNT}-\mathrm{SO}_{3} \mathrm{H}\right)$.

The Pd-decorated core-shell structures were obtained by mixing $0.20 \mathrm{~g}$ of FeCo@Fe/MWCNT-COOH or FeCo@Fe/MWCNT-SO 3 H with 0.35 g ( 2 mmol $)$ of $\mathrm{PdCl}_{2}$ salt in ethylene glycol solution containing polyvinylpyrolidone and subjecting it to a rapid microwave irradiation (Anton Parr Synthos 3000 microwave reactor) at $500 \mathrm{~W}$, 80 bars, and $\sim 198{ }^{\circ} \mathrm{C}$ for $15 \mathrm{~min}$. The solid product was obtained by centrifugation by repeatedly washed with acetone and deionised water to remove traces of ethylene glycol and other impurities, and then dried at $100{ }^{\circ} \mathrm{C}$. Based on the HRTEM (or ARTEM) results, the final Pd-based product is abbreviated as FeCo@ $\mathrm{Fe} @ \mathrm{Pd} / \mathrm{MWCNT}-\mathrm{COOH}$ or FeCo@Fe@Pd/MWCNT-SO 3 H. For comparison, Pd/MWCNT-COOH or Pd/MWCNT$\mathrm{SO}_{3} \mathrm{H}$ nanoparticles of same Pd loading as the core-shell were also synthesized using the same microwave procedure.

\section{Physical characterizations}

Powder XRD analysis was performed with PANalytical X'Pert powder diffractometer with $\mathrm{Co} \mathrm{K} \alpha$ radiation. SEM images were obtained with a field emission scanning electron microscope (FESEM, Zeiss-Leo DSM982). TEM images were taken on a JEOL JEM 2000EX microscope at an accelerating voltage of $200 \mathrm{kV}$, while atomic resolution TEM images were acquired from JEOL ARM200F equipped with energy dispersive X-ray (EDX) spectrometer and highest level high-angle annular dark field scanning transmission electron microscopy (HAADF-STEM) resolution of $78 \mathrm{pm}$ with a STEM Cs corrector incorporated as standard. The morphology and elemental composition of the materials were analysed using an FEI Helios NanoLab 650 scanning electron microscope (SEM) and a Jeol JEM-ARM200F atomic resolution transmission electron microscope (ARTEM). Samples for ARTEM analyses were prepared by dispersing the nanoparticles in methanol, sonicating for about $2 \mathrm{~min}$ in order to ensure adequate dispersion of the nanostructures. A 300 mesh $\mathrm{Cu}$ grid, coated with a lacy carbon film was carefully dipped into each suspension of nanoparticles. This was done to avoid and over agglomeration of the nanoparticles on the grids. The metal contents of the nanocatalysts were determined using inductively coupled plasma atomic emission spectroscopy (ICP-AES) with an Intrepid Iris instrument (Thermo Elemental). Each sample $(50 \mathrm{mg}$ ) was treated in a microwave heated digestion bomb in sealed PTFE vessels with concentrated $\mathrm{HNO}_{3}(2.0$ $\mathrm{mL})$ and $98 \% \mathrm{H}_{2} \mathrm{SO}_{4}(2 \mathrm{~mL})$. The heating program comprised some preheating steps and a final 10 min digestion step at $220{ }^{\circ} \mathrm{C}$. The resulting residual solutions were diluted with water to constant volume. The solutions were then analysed for the metal content. Raman spectroscopy data were collected using a Jobin-Yvon Horiba TX 6400 micro-Raman spectrometer equipped with a triple monochromatic system to eliminate contributions from Rayleigh scattering. The samples were analysed with a $514 \mathrm{~nm}$ argon excitation laser (1.5 $\mathrm{mW}$ laser power on the sample to avoid thermal effects), using a 509 objective with acquisition time of $120 \mathrm{~s}$. Fourier transmission infrared spectroscopy (FTIR) analyses were carried out using a Bomem (Hartmann \& Braun), model MB-102 spectrophotometer. X-ray Photoelectron Spectroscopy (XPS) was performed with an Al 
monochromatic K $\alpha$ source (1486.6 eV) using the XPS Peak 4.1 program and a Shirley function to subtract the background.

\section{Electrochemical measurements}

Electrochemical experiments were carried out at room temperature with a conventional three-electrode configuration using an Autolab potentiostat PGSTAT 100 (Eco Chemie, Utrecht, Netherlands) driven by the General Purpose Electrochemical Systems data processing software (GPES software version 4.9). The working electrode was a modified glassy carbon disk electrode (GCE, Bioanalytical systems, diameter $=3.0 \mathrm{~mm}$ ). A Pt rod and $\mathrm{Ag} \mid \mathrm{AgCl}(3 \mathrm{M} \mathrm{KCl})$ were used as a counter and reference electrode, respectively. All solutions were de-aerated by bubbling pure nitrogen prior to each electrochemical experiment. Before each measurement the GCE was polished to a mirror finish using alumina slurry (nanopowder Aldrich) and then cleaned by ultrasonic stirring in ethanol and acetone for $3 \mathrm{~min}$, respectively. To prepare the catalyst ink, $10.0 \mathrm{mg}$ of the catalyst were dispersed in $10.0 \mathrm{~mL}$ of ethanol containing $1 \mathrm{~mL}$ of $5 \%$ Nafion solution (DuPont). The mixture was ultrasonicated for about 3 min to make a uniform ink. The GCE was modified by dropping $6 \mu \mathrm{L}$ of the catalyst ink on its surface and allowing it to dry in an oven at about $60^{\circ} \mathrm{C}$. The Pd loading was estimated by weight and was approx. $1.37 \mu \mathrm{g}$ for each electrode. Every electrochemical experiment on the oxidation of glycerol and ethylene glycol in 1.0 M KOH was performed after degassing with high purity nitrogen. The membrane electrode assemblies (MEAs) for the passive monoplanar cells were carried out to provide some preliminary insights into the real-time fuel cell performance for anion-exchange membrane direct ethylene glycol fuel cell (AEM-DEGFC) and direct glycerol fuel cell (AEM-DGFC) using a commercial Tokuyama A-201 AEM and cathodes containing a proprietary $\mathrm{Fe}-\mathrm{Co} / \mathrm{C}$ electrocatalyst on carbon cloth. ${ }^{39}$ The cell hardware has been described previously. ${ }^{40}$ The membrane was conditioned in a saturated $\mathrm{KOH}$ solution for $1 \mathrm{~min}$ before assembling the MEA. The volume of the anode compartment was ca. $25 \mathrm{~mL}$ for actual $10.5 \mathrm{~mL}$ of fuel solution $(5 \mathrm{wt} \%$ alcohol and $2 \mathrm{M}$ $\mathrm{KOH})$. The anode electrode was constructed with a $5.13 \mathrm{~cm}^{2}$ nickel foam plate, onto which the appropriate amount of dense catalytic ink was deposited. This was prepared by introducing the catalyst $(100 \mathrm{mg}$ ) into a $5 \mathrm{~mL}$ polyethylene container together with water $(50 \mathrm{mg})$. The metal loading on each electrode was determined by weighing the amount of ink deposited $\left(\sim 5 \mathrm{mg} \mathrm{cm}^{-2}\right)$. The MEA was obtained by mechanically pressing anode, cathode, and membrane. For a reliable evaluation of the oxidation products, the anode compartment was sealed under a nitrogen atmosphere, whereas the cathode was exposed to either air or oxygen with no significant variation of the cell performance. This was evaluated using an ARBIN BT-2000 5A four-channel instrument. The operating temperatures were in the range of $15-18{ }^{\circ} \mathrm{C}$. The fuel oxidation products were qualitatively and quantitatively determined by means of ${ }^{13} \mathrm{C}\left\{{ }^{1} \mathrm{H}\right\}$ NMR spectroscopy using appropriate calibration curves. Galvanostatic experiments were carried out at room temperature on the passive cells where the anode compartment was filled with $10.5 \mathrm{~mL}$ of $5 \mathrm{wt} \% \mathrm{EG}$ or $\mathrm{G}$ in $2 \mathrm{M} \mathrm{KOH}$ solution (8.47 and $5.70 \mathrm{mmol}$, respectively). After a conditioning time of $1 \mathrm{~h}$ at the OCV, the circuit of the DEGFC or DGFC was closed and a constant current of $102 \mathrm{~mA}\left(20 \mathrm{~mA} \mathrm{~cm}^{-2}\right)$ was allowed to flow until the cell voltage reached zero. The solution was not refuelled during the experiment. 


\section{Results and discussion}

\section{Spectroscopy and microscopic characterization}

The main aim of the study is to use literature-established techniques to functionalise MWCNTs with $-\mathrm{COOH}$ or $-\mathrm{SO}_{3} \mathrm{H}$ and subsequently use them as support for the Pdbased core-shell catalysts for ADAFCs. FTIR data (see ESI, Fig. S1 $\uparrow$ ) confirmed the successful functionalization of the MWCNTs a with $-\mathrm{COOH}$ or $-\mathrm{SO}_{3} \mathrm{H}$ functional groups. The MWCNT-COOH showed intense band at $3428 \mathrm{~cm}^{-1}$ due to the stretching vibrational modes of the $\mathrm{O}-\mathrm{H}$ group, and 1719 and $1587 \mathrm{~cm}^{-1}$ due to the $\mathrm{C}=\mathrm{O}$ stretching vibrations from carboxylic and carbonyl groups. Interestingly, upon sulphonation of the MWCNT-COOH, the intense bands due to the $\mathrm{OH}\left(3428 \mathrm{~cm}^{-1}\right)$ and $\mathrm{C}=\mathrm{O}(1719$ and 1587 $\mathrm{cm}^{-1}$ ) groups disappeared leading to two strong bands at 1467 and $1380 \mathrm{~cm}^{-1}$ which are the characteristic absorption bands of organic sulfonate groups; the $\mathrm{O}=\mathrm{S}=\mathrm{O}$ asymmetric and $\mathrm{O}=\mathrm{S}=\mathrm{O}$ symmetric stretching motions respectively. The Raman spectra (see ESI, Fig. $\mathrm{S} 2 \dagger$ ) confirmed the degree of functionalization of the pristine MWCNTs with the $\mathrm{COOH}$ or $-\mathrm{SO}_{3} \mathrm{H}$. The vales of the intensity ratios $\left(\mathrm{I}_{\mathrm{D}} / \mathrm{I}_{\mathrm{G}}\right)$ of the D-band of the MWCNTs $\left(\mathrm{sp}^{3} \mathrm{C}\right)$ and graphitic band $\left(\mathrm{sp}^{2} \mathrm{C}\right)$ for the MWCNT-COOH, MWCNT-SO $\mathrm{S}_{3} \mathrm{H}$ and pristine MWCNTs were calculated as $0.90 \pm 0.14,0.88 \pm 0.12$ and $0.72 \pm 0.10$, respectively, indicating that the degree of functionalization of MWCNT-COOH and MWCNT- $\mathrm{SO}_{3} \mathrm{H}$ is essentially the same.

Next, it was necessary to establish the core-shell nature of the precursor material (FeCo@Fe) and its palladium-decorated core-shell material (FeCo@Fe@Pd), and to do this we used atomic resolution TEM. Fig. 1 shows typical high-angle annular dark-field (HAADF)- and bright-field (BF)-STEM images simultaneously acquired for the FeCo@Fe@Pd/MWCNT-COOH to get complete information of the nanostructures. It is common knowledge that in the HAADF-STEM mode, the metal particle with high atomic numbers appears as bright contrast, while those with low atomic numbers appear as dark contrast. ${ }^{41,42}$ The HAADF-STEM image shows brighter contrast in the shell and darker contrast in the core, which is a clear indication that the core contains lighter elements ( $\mathrm{Fe}$ and $\mathrm{Co}$ ) than the shell. In the BF-STEM image, however, the particles with heavy atoms should appear as dark contrast since they are the heaviest scatterers in this system. Our BF-STEM image clearly corroborates the HAADF-STEM image. From the STEM images, there are some free Pd nanoparticles that co-exist with the core-shell nanoparticles. Also, during the acquisition of the STEM data, we observed the coexistence of oxides of palladium $\left(\mathrm{Pd}_{\mathrm{x}} \mathrm{O}_{\mathrm{y}}\right)$ and iron $\left(\mathrm{Fe}_{\mathrm{x}} \mathrm{O}_{\mathrm{y}}\right)$. 

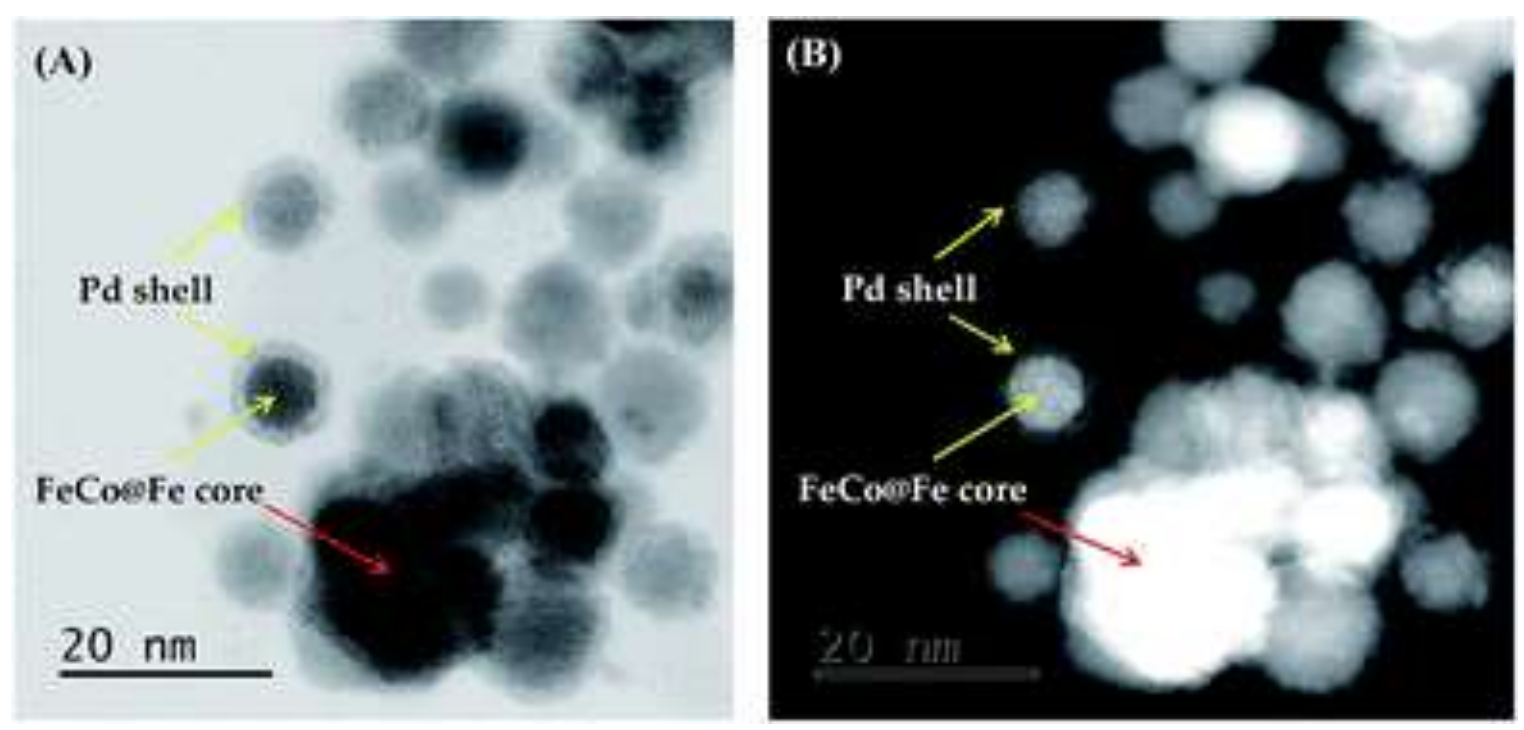

Fig. 1 (A) High-angle annular dark-field (HAADF)- and (B) bright-field (BF)-STEM images simultaneously acquired for the FeCo@Fe@Pd/MWCNT-COOH.

Electron energy loss spectral (EELS) images of core at different MWCNT supports (see ESI, Fig. S3†) show clear contrasts between the inner FeCo alloy and the segregated $\mathrm{Fe} / \mathrm{Fe}_{\mathrm{x}} \mathrm{O}_{\mathrm{y}}$ shell around the edges of the core-shell, irrespective of the type of MWCNTs used as support. Since the materials were synthesised under inert atmosphere, and the HRTEM experiments performed in ultrahigh vacuum, the most plausible source of the metal oxides could be during transportation or sample-handling. XPS data (see ESI, Fig. $\mathrm{S} 4 \dagger$ ) proves the existence of the $\mathrm{PdO}$ species. In fact, the presence of the PdO species is not surprising as $\mathrm{Pd}$ is well known to easily oxidize to $\mathrm{PdO}$ in air. The presence of the oxides is an advantage for the electrocatalysis. ${ }^{38,43,44}$ The intense dark portions of the HAADF-STEM (Fig. 1A, red arrow) or the intense bright portions of the BF-STEM images (Fig. 1B, red arrow) showed that few of the nanosized FeCo@Fe were not completely decorated with the Pd nanoskin. Further experiments are necessary to interrogate this observation with a view to rectifying and optimising the MITNAD strategy process.

Fig. 2 compares the FESEM images of the precursor core-shell materials, FeCo@Fe/MWCNT-COOH (Fig. 2A) and FeCo@Fe/MWCNT-SO 3 H (Fig. 2C) and their corresponding Pd-decorated catalysts FeCo@Fe@Pd/MWCNT-COOH (Fig. 2B) and FeCo@Fe@Pd/MWCNT-SO 3 H (Fig. 2D), respectively. The precursor materials, irrespective of the type of MWCNT support used, are large particle sizes (between 140 and $600 \mathrm{~nm}$ ) while the Pd-decorated counterparts are sub-10 nm in sizes, with the Pd skin or thickness being ca. $3 \mathrm{~nm}$. We observed the same phenomenon with Vulcan XC-72 support, ${ }^{33}$ meaning that the microwave-induced top-down nanostructuring of FeCo@ $\mathrm{Fe}$ and simultaneous decoration with Pd (MITNAD strategy) occurs irrespective of the carbon support. However, it is interesting to observe in this present work that Pd catalyst prepared using the same microwave strategy, Pd/MWCNT-COOH and Pd/MWCNT$\mathrm{SO}_{3} \mathrm{H}$ (Fig. 3), gave large-sized Pd catalysts (up to $\geq 200 \mathrm{~nm}$ ). This result suggests that the formation of the sub-10 nm FeCo@Fe@Pd via our microwave-assisted solvothermal 
process must have been made possible by the magnetic nature of the FeCo@ $\mathrm{Fe}$ coreshell alloy. In other words, the interaction of the magnetic FeCo@Fe with the microwave irradiation (magneto-microwave interaction) led to the immediate breakdown (nanosizing) of the FeCo@Fe that only permitted the formation of a thin-skin rather than a thick-skin Pd coverage of the FeCo@Fe core-shell.
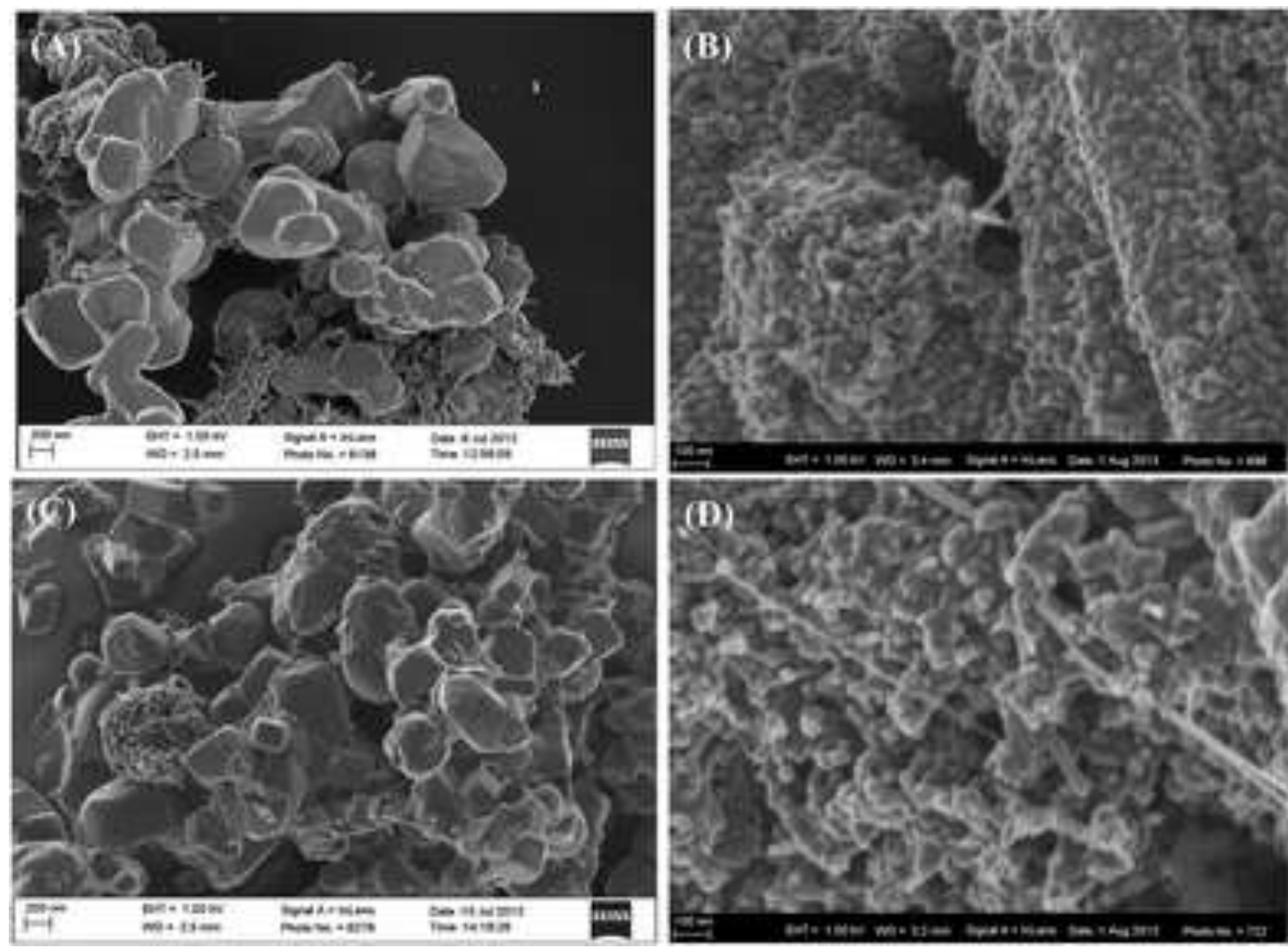

Fig. 2 FESEM images of (A) FeCo@Fe/MWCNT-COOH, (B) FeCo@Fe@Pd/MWCNT-COOH, (C) FeCo@Fe/MWCNT-SO $3 \mathrm{H}$ and (D) FeCo@Fe@Pd/MWCNT-SO 3 H.
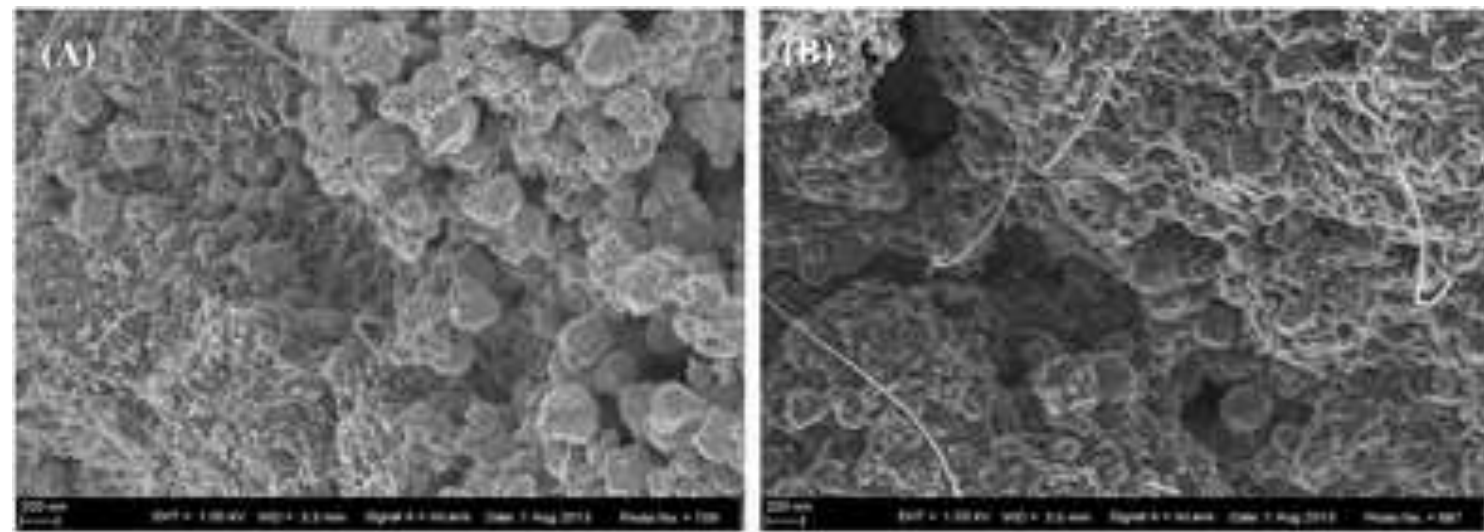

Fig. 3 FESEM images of (A) Pd/MWCNT-COOH and (B) Pd/MWCNT-SO ${ }_{3} \mathrm{H}$. 
Another important observation of the FESEM images is that the MWCNT-COOH support (weak acidic character) allowed for a more uniform dispersion and higher loading of the FeCo@Fe@Pd nanocatalyts compared to the MWCNT-SO $\mathrm{M}_{3} \mathrm{H}$ support (strong acidic character). It is probable that the $\mathrm{Pd}$ reduction was not fully performed at the MWCNTs with the highest acidic character $\left(-\mathrm{SO}_{3} \mathrm{H}\right)$. This perhaps should not be totally surprising considering that a similar observation has been reported by Kim and Park ${ }^{45}$ for Pt catalysts where carbon black treated with acid showed poor catalyst loading compared to the base-treated or neutral carbon blacks.

Fig. 4 compares the powder XRD patterns of the four Pd-based catalysts; FeCo@Fe@Pd/MWCNT-COOH, FeCo@Fe@Pd/MWCNT-SO 3 H, Pd/MWCNT-COOH and $\mathrm{Pd} / \mathrm{MWCNT}-\mathrm{SO}_{3} \mathrm{H}$. They can be indexed to the face centred cubic (fcc) structure (SP-group Fm $\overline{3}$ m, JCPDS card: 03-065-6174). They displayed diffraction peaks at $2 \theta$ (hkl) values of $46.9^{\circ}(111), 54.7^{\circ}(200), 81.1^{\circ}(220), 99.4^{\circ}(311)$ and $105.7^{\circ}(222)$ corresponding to a typical face centred structure of Pd. The shifts in the diffraction peaks to the higher $2 \theta$ positions of the two core-shell nanocatalysts are indicative of lattice contraction upon introduction of the FeCo@Fe alloy in the Pd lattice. From the Vergard's law, our calculation indicates the Pd lattice contracted from $3.8898 \AA$ in Pd to 3.8735 and 3.8767 A for FeCo@Fe@Pd/MWCNT-COOH and FeCo@Fe@Pd/MWCNT-SO 3 H, respectively. This lattice strain effect has already been observed on Pd alloys with Pd-rich surface incorporated with other atoms. ${ }^{46-48}$ The intense peaks of the Pd/MWCNT-COOH and $\mathrm{Pd} / \mathrm{MWCNT}-\mathrm{SO}_{3} \mathrm{H}$ indicate high crystallinity and large-sized particles. Interestingly, the full width of half maximum (FWHM) of the diffraction peaks of the catalysts are broader when they are supported on the MWCNT-COOH than when they are on the MWCNT-SO $\mathrm{S}_{3} \mathrm{H}$ support, meaning that the particle sizes of the Pd and FeCo@Fe@Pd are smaller on MWCNT-COOH than on the MWCNT-SO $\mathrm{MH}_{3} \mathrm{H}$ support. This was further confirmed from the Scherrer equation, using the Gaussian fitted (220) peak, where the core-shell particle sizes decreased as follows: FeCo@Fe@Pd/MWCNT-SO $3 \mathrm{H}(10.8 \mathrm{~nm})$ > FeCo@Fe@Pd/MWCNT-COOH (7.4 nm). 


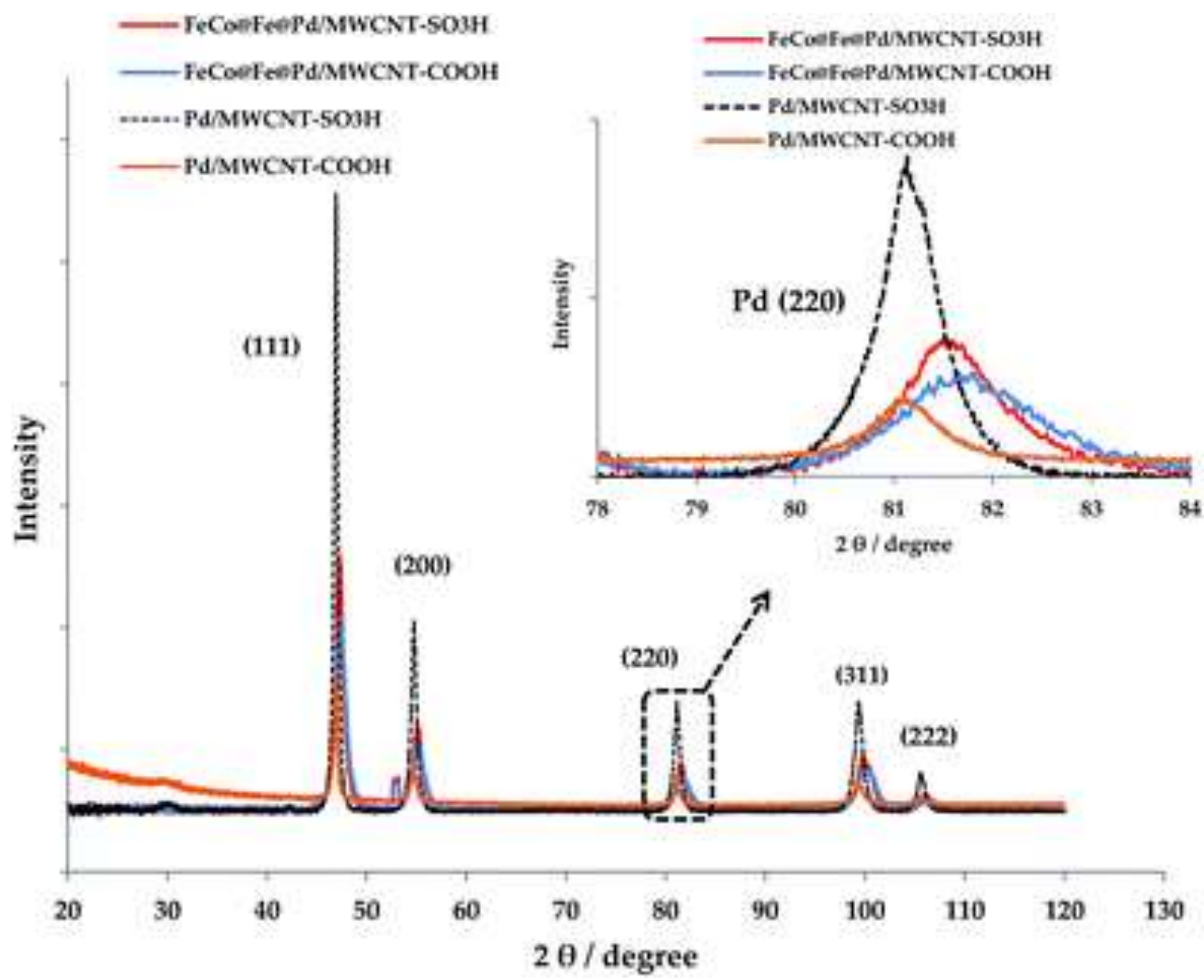

Fig. 4 XRD patterns of FeCo@Fe@Pd/MWCNT-SO 3 H, FeCo@Fe@Pd/MWCNT-COOH, Pd/MWCNT$\mathrm{COOH}$ and $\mathrm{Pd} / \mathrm{MWCNT}-\mathrm{SO}_{3} \mathrm{H}$. Inset shows the expanded portion of the Pd (220) diffraction peaks.

\section{Electrocatalytic oxidation of ethylene glycol and glycerol}

Fig. 5 shows the cyclic voltammograms (CVs) of the catalysts including the precursor FeCo@Fe obtained in a nitrogen-saturated $1.0 \mathrm{M} \mathrm{KOH}$ solution at a scan rate of $50 \mathrm{mV}$ $\mathrm{s}^{-1}$. The CVs of the four Pd-based electrodes gave the expected signature peaks of the Pd in alkaline electrolytes. On the other hands, the two electrodes without Pd (i.e., the precursor FeCo@Fe) did not show any detectable peaks in the potential window. The four Pd-based catalysts exhibit a common Pd surface reduction peak at ca. $-0.35 \mathrm{~V}$ vs. $\mathrm{Ag} \mid \mathrm{AgCl}$ (for $\mathrm{Pd} / \mathrm{MWCNT}-\mathrm{COOH}$ and $\mathrm{Pd} / \mathrm{MWCNT}-\mathrm{SO}_{3} \mathrm{H}$ ) and $-0.38 \mathrm{~V}$ vs. $\mathrm{Ag} \mid \mathrm{AgCl}$ (for FeCo@Fe@Pd/MWCNT-SO 3 H and FeCo@Fe@Pd/MWCNT-COOH). Using the established method of determining the electrochemically-active surface area (EASA) from the PdO reduction peak ${ }^{49}$ with our Pd loading on the GCE of $1.37 \mu \mathrm{g}$ (ca. $20 \mu \mathrm{g}$ $\mathrm{cm}^{-2}$ ), the EASA values were estimated as 74.63, 42.26, 8.10, and $9.98 \mathrm{~m}^{2} \mathrm{~g}^{-1}$ for the FeCo@Fe@Pd/MWCNT-COOH, FeCo@Fe@Pd/MWCNT-SO 3 H, Pd/MWCNT-COOH, and $\mathrm{Pd} / \mathrm{MWCNT}-\mathrm{SO}_{3} \mathrm{H}$, respectively. 


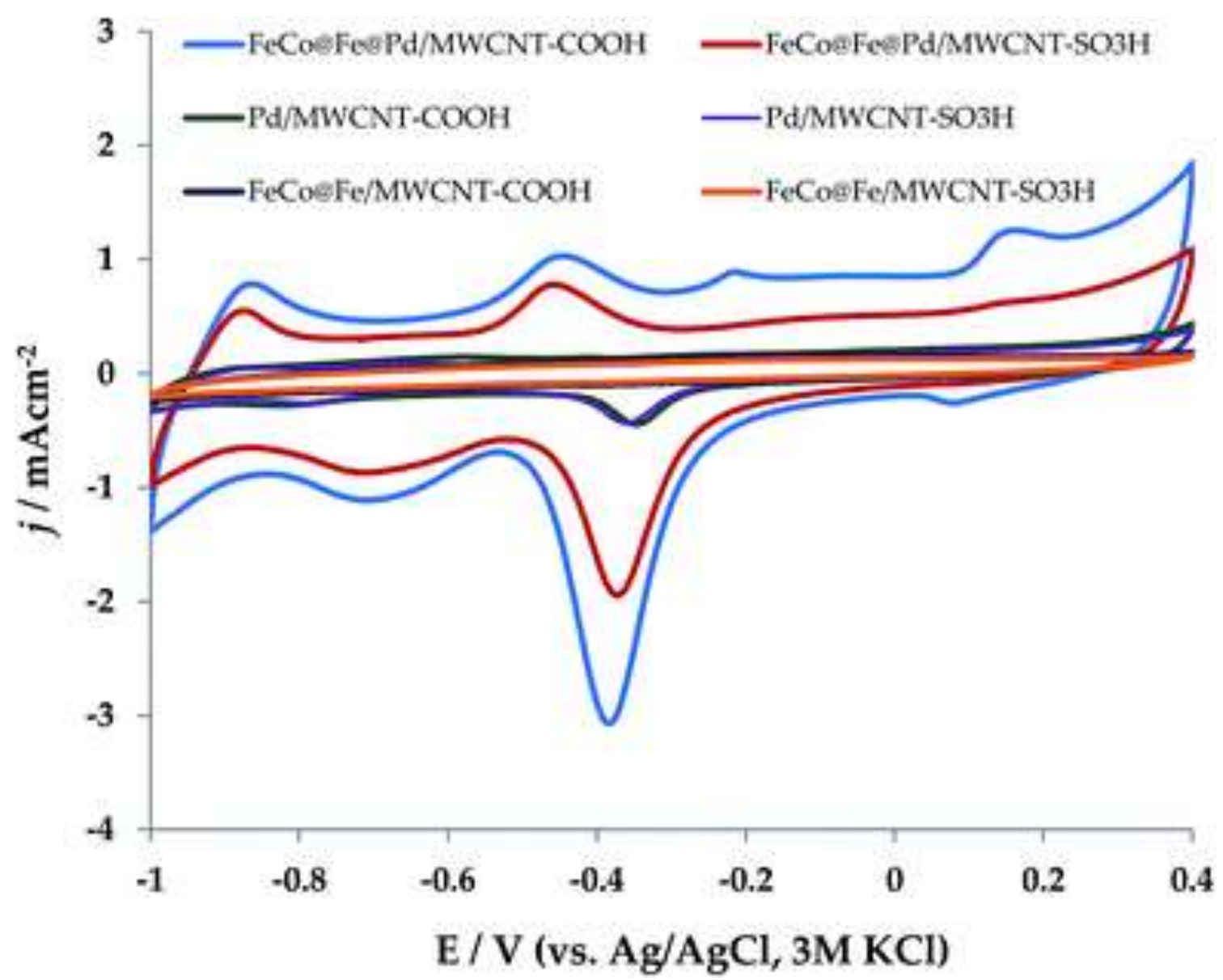

Fig. 5 Comparative cyclic voltammograms of FeCo@Fe@Pd/MWCNT-COOH, FeCo@Fe@Pd/MWCNT-SO 3 H, Pd/MWCNT-COOH, Pd/MWCNT-SO 3 H, FeCo@Fe/MWCNT-COOH and $\mathrm{FeCo} @ \mathrm{Fe} / \mathrm{MWCNT}-\mathrm{SO}_{3} \mathrm{H}$ in nitrogen-saturated $1 \mathrm{M} \mathrm{KOH}$ scan rate $=50 \mathrm{mV} \mathrm{s}^{-1}$.

Fig. 6A and B compare the CVs of the catalysts including the precursor FeCo@Fe obtained in 1.0 M KOH solution containing 0.5 M EG (Fig. 6A) or 0.5 M GLY (Fig. 6B) at a scan rate of $50 \mathrm{mV} \mathrm{s}^{-1}$. As expected, the precursor FeCo@ $@$ Fe materials did not give any detectable peaks for the alcohol oxidation in the selected potential window, thus proving that the observed catalysis was due to the presence of Pd. 

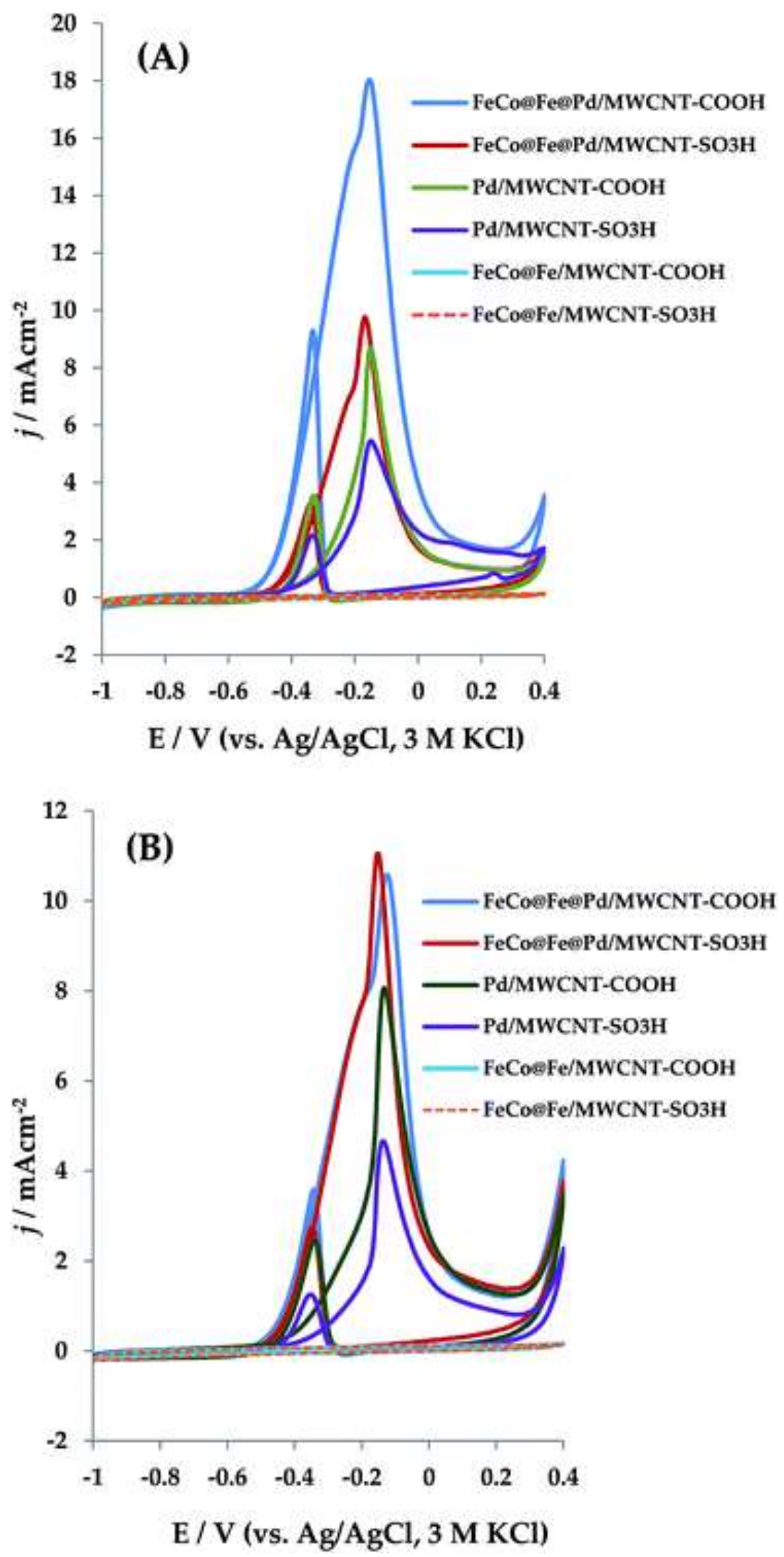

Fig. 6 Cyclic voltammetric evolutions of the oxidation of (A) $0.5 \mathrm{M} \mathrm{EG}$ and (B) $0.5 \mathrm{M}$ GLY in $1 \mathrm{M} \mathrm{KOH}$ using the various catalyst platforms. Scan rate $=50 \mathrm{mV} \mathrm{s}^{-1}$. 
Scan rate studies for the EG and GLY (up to $800 \mathrm{mV} \mathrm{s}^{-1}$, not shown) showed linear relationships between peak current density versus square root of the scan rate, confirming diffusion-controlled electrocatalytic processes for the catalysts. The CV parameters for the electrocatalytic performance for each catalysts are summarised in Table 1. The ratio of the forward anodic peak to the backward peak current density $\left(\mathrm{J}_{\mathrm{f}} / \mathrm{J}_{\mathrm{b}}\right)$ relates to the ability of the catalyst to tolerate carbonaceous species, ${ }^{47,50,51}$ thus it should generally be a higher value for the best-performing catalyst. The onset potential $\left(E_{\text {onset }}\right)$ and peak potential for the forward reaction $\left(\mathrm{E}_{\text {peak }}\right)$ describe the ease at which electro-oxidation occurs at the catalyst, thus they should be less positive for the best-performing electrocatalysts. Despite the large literature on this argument, it is believed that the ratio between the forward peak and the backward should be only associated with the upper inverted potential. Indeed, at high potential, are formed surface palladium oxides that are inactive for the electrooxidation of alcohols. ${ }^{30,52}$ The backward scan peak can be associated with the oxidation of freshly chemisorbed EG or GLY. In fact, previous CV studies of ethanol oxidation on Pd showed that the decrease in current at high voltages was mainly due to the formation of a PdO layer, which blocked the adsorption of the substrate. ${ }^{52}$ The electrocatalytic activity was restored in the negative-going sweep once the potential reached the value at which $\mathrm{PdO}$ was reduced to $\mathrm{Pd}$. On the other hand, one cannot rule out that a contribution to the current fade may be due to mass transfer phenomena as well as to the instantaneous shortage of $\mathrm{OH}^{-}$groups in the thin layer. In fact, according to literature, adsorbed hydroxyl species are required to release the carboxylic acid upon coupling with Pd-acyl species. ${ }^{30,53}$

Table 1 Comparison of voltammetric data of Pd-based catalysts in this work, all potentials obtained at 50 $\mathrm{mV} \mathrm{s}^{-1}$ and measured versus $\mathrm{Ag} \mid \mathrm{AgCl}(3 \mathrm{M} \mathrm{KCl}), \mathrm{Pd}$ loading of ca. $20 \mu \mathrm{g} \mathrm{cm}^{-2}$. Each experiment was run five times

\begin{tabular}{|c|c|c|c|c|c|}
\hline Pd-based catalyst & Alcohol solution & \begin{tabular}{|l} 
EASA/m \\
$\mathrm{g}^{1}$
\end{tabular} & $\mathbf{E}_{\text {onset }} / \mathbf{V}$ & $\mathbf{E}_{\text {peak }} / \mathbf{V}$ & $\mathbf{J}_{\mathbf{f}} / \mathbf{J}_{\mathbf{b}}$ \\
\hline $\begin{array}{l}\text { FeCo@Fe@Pd/MWCNT- } \\
\mathrm{COOH}\end{array}$ & \multirow[t]{4}{*}{$0.5 \mathrm{M} \mathrm{EG} / 1.0 \mathrm{M} \mathrm{KOH}$} & $\begin{array}{l}74.63 \pm \\
3.61 \\
\end{array}$ & $\begin{array}{l}-0.58 \pm \\
0.03 \\
\end{array}$ & $\begin{array}{l}-0.16 \pm \\
0.01 \\
\end{array}$ & $\begin{array}{l}2.05 \pm \\
0.10\end{array}$ \\
\hline $\mathrm{FeCo@Fe@Pd/MWCNT-SO}{ }_{3} \mathrm{H}$ & & $\begin{array}{l}42.26 \pm \\
2.10 \\
\end{array}$ & $\begin{array}{l}-0.52 \pm \\
0.03\end{array}$ & $\begin{array}{l}-0.17 \pm \\
0.01 \\
\end{array}$ & $\begin{array}{l}3.01 \pm \\
0.14\end{array}$ \\
\hline $\mathrm{Pd} / \mathrm{MWCNT}-\mathrm{COOH}$ & & $8.10 \pm 0.38$ & \begin{tabular}{|l}
$-0.44 \pm$ \\
0.02 \\
\end{tabular} & $\begin{array}{l}-0.16 \pm \\
0.01 \\
\end{array}$ & $\begin{array}{l}2.50 \pm \\
0.13\end{array}$ \\
\hline $\mathrm{Pd} / \mathrm{MWCNT}-\mathrm{SO}_{3} \mathrm{H}$ & & $9.98 \pm 0.41$ & $\begin{array}{l}-0.43 \pm \\
0.02 \\
\end{array}$ & $\begin{array}{l}-0.16 \pm \\
0.01 \\
\end{array}$ & $\begin{array}{l}2.60 \pm \\
0.13\end{array}$ \\
\hline $\begin{array}{l}\mathrm{FeCo@Fe@Pd/MWCNT-} \\
\mathrm{COOH}\end{array}$ & \multirow[t]{4}{*}{$\begin{array}{l}0.5 \mathrm{M}(\mathrm{GLY}) / 1.0 \mathrm{M} \\
\mathrm{KOH}\end{array}$} & $\begin{array}{l}74.63 \pm \\
3.61 \\
\end{array}$ & $\begin{array}{l}-0.57 \pm \\
0.03\end{array}$ & $\begin{array}{l}-0.13 \pm \\
0.01 \\
\end{array}$ & $\begin{array}{l}3.05 \pm \\
0.15\end{array}$ \\
\hline FeCo@Fe@Pd/MWCNT-SO $3 \mathrm{H}$ & & $\begin{array}{l}42.26 \pm \\
2.10 \\
\end{array}$ & $\begin{array}{l}-0.54 \pm \\
0.03\end{array}$ & $\begin{array}{l}-0.16 \pm \\
0.01 \\
\end{array}$ & $\begin{array}{l}4.09 \pm \\
0.20\end{array}$ \\
\hline $\mathrm{Pd} / \mathrm{MWCNT}-\mathrm{COOH}$ & & $8.10 \pm 0.38$ & $0.51 \pm 0.03$ & $\begin{array}{l}-0.14 \pm \\
0.01 \\
\end{array}$ & $\begin{array}{l}3.36 \pm \\
0.17\end{array}$ \\
\hline $\mathrm{Pd} / \mathrm{MWCNT}-\mathrm{SO}_{3} \mathrm{H}$ & & $9.98 \pm 0.41$ & $0.47 \pm 0.02$ & $0.14 \pm 0.01$ & $\begin{array}{l}3.96 \pm \\
0.20\end{array}$ \\
\hline
\end{tabular}


For the EG oxidation, FeCo@Fe@Pd/MWCNT-COOH showed high current density, which is approximately twice that of the FeCo@Fe@Pd/MWCNT-SO $3 \mathrm{H}$. In addition, the FeCo@Fe@Pd/MWCNT-COOH gave an $\mathrm{E}_{\text {onset }}$ of $-0.58 \mathrm{~V}$ which is lower than that of $\mathrm{FeCo} @ \mathrm{Fe} @ \mathrm{MWCNT} / \mathrm{SO}_{3} \mathrm{H}$ at $0.52 \mathrm{~V}$. This value is ca. $140 \mathrm{mV}$ earlier than the $\mathrm{E}_{\text {onset }}$ value of Pd/MWCNT-COOH $(-0.44 \mathrm{~V})$ and ca. $150 \mathrm{mV}$ earlier than that of the $\mathrm{Pd} / \mathrm{MWCNT}-\mathrm{SO}_{3} \mathrm{H}(-0.43 \mathrm{~V})$. FeCo@Fe@Pd/MWCNT-COOH gave a current response of $17.80 \mathrm{~mA} \mathrm{~cm}^{-2}$ current density to EG oxidation, which is ca. 2 times higher than that of both FeCo@Fe@Pd/MWCNT-SO $3 \mathrm{H}\left(9.67\right.$ mA cm $\left.{ }^{-2}\right)$ and Pd/MWCNT-COOH (8.53 $\mathrm{mA} \mathrm{cm}{ }^{-2}$ ). It is also 3.3 times higher than that of Pd/MWCNT-SO $3 \mathrm{H}$ with $5.37 \mathrm{~mA} \mathrm{~cm}{ }^{-2}$. For the GLY, the $\mathrm{E}_{\text {onset }}$ of GLY is situated at $-0.57 \mathrm{~V}$ for $\mathrm{FeCo} @ \mathrm{Fe} @ \mathrm{Pd} / \mathrm{MWCNT}-$ $\mathrm{COOH}$ which is earlier than $-0.54 \mathrm{~V}$ at FeCo@Fe@Pd/MWCNT-SO $3 \mathrm{H},-0.512 \mathrm{~V}$ at $\mathrm{Pd} / \mathrm{MWCNT}-\mathrm{COOH}$ and $-0.468 \mathrm{~V}$ at $\mathrm{Pd} / \mathrm{MWCNT}-\mathrm{SO}_{3} \mathrm{H}$. Both FeCo@Fe@Pd/MWCNT-COOH and FeCo@Fe@Pd/MWCNT-SO 3 H exhibited high oxidation peak current density of about $11.00 \mathrm{~mA} \mathrm{~cm}^{-2}$ which is 1.3 times higher than $\mathrm{Pd} / \mathrm{MWCNT}-\mathrm{COOH}\left(8.03 \mathrm{~mA} \mathrm{~cm}{ }^{-2}\right)$ and 2.7 times higher than Pd/MWCNT-SO ${ }_{3} \mathrm{H}$. The $\mathrm{J}_{\mathrm{f}} / \mathrm{J}_{\mathrm{b}}$ values for the four catalysts are above 2 for EG but above 3 for the GLY. This indicates excellent tolerance of the catalysts to the presence of the carbonaceous products from alcohol oxidation. In every case, the Pd core-shell catalysts exhibit better oxidative electrocatalytic properties compared to the monometallic Pd catalysts. In general, the CV data (Table 1) clearly indicate that the catalysts on the MWCNT-COOH supports exhibit the best catalytic activity for both EG and GLY compared those on the MWCNT-SO ${ }_{3} \mathrm{H}$ supports. These results are consistent with the inherent properties of the MWCNT-COOH support, which include the more efficient and uniform dispersion of the catalysts (Pd and FeCo@Fe@Pd), smaller nanoparticulate sizes, and higher EASA.

Stability is another important factor for the potential application of a catalyst in fuel cells. The stability of the four catalysts was studied using a conventional chronoamperometric technique. Fig. 7 compares the chronoamperometric evolutions in $\mathrm{KOH}$ solutions of EG (Fig. 7A) and GLY (Fig. 7B) at a fixed potential of $0.16 \mathrm{~V}$ vs. Ag|AgCl. After the initial current decay, probably due to the deactivation of the Pd catalytic sites arising from chemisorbed carbonaceous species during alcohol oxidation, ${ }^{54}$ the chronoamperograms gradually attained a pseudo-steady state. As seen in the current densities for both EG and GLY, FeCo@Fe@Pd/MWCNT-COOH exhibited the highest initial current and the slowest decay rate amongst the catalysts. The FeCo@Fe@Pd/MWCNT-COOH also maintained the highest oxidation current density at the pseudo-steady state, thus giving the best electrocatalytic activity and stability. In addition, the pseudo-steady state current for the FeCo@Fe@Pd/MWCNT-COOH was higher for the EG compared to that for the GLY. 

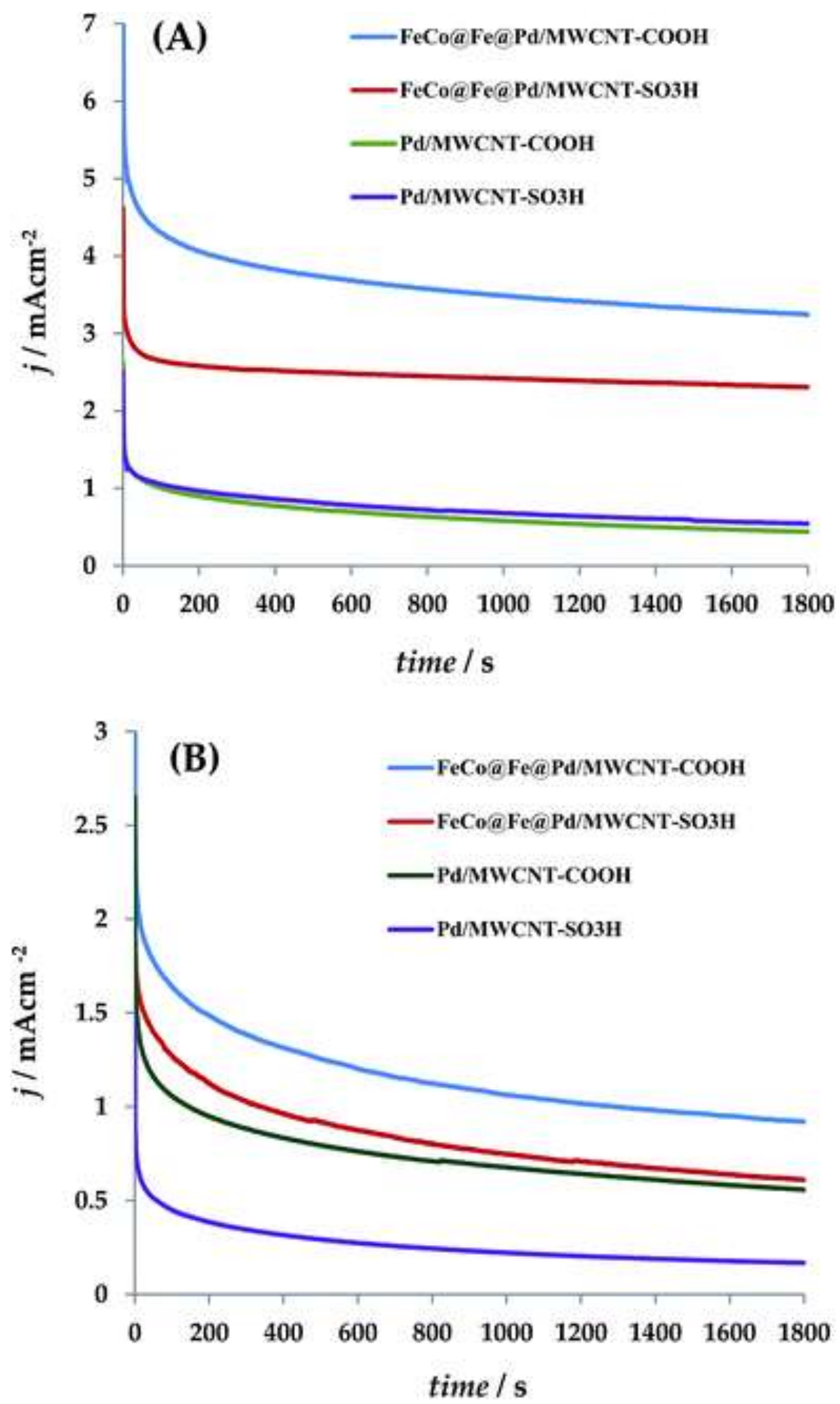

Fig. 7 Chronoamperometric curves of the various catalysts in (A) $0.5 \mathrm{M} \mathrm{EG} / 1.0 \mathrm{M} \mathrm{KOH}$ and (B) $0.5 \mathrm{M}$ $\mathrm{GLY} / 1 \mathrm{M} \mathrm{KOH}$ at a fixed potential of $0.16 \mathrm{~V}$ vs. $\mathrm{Ag} \mid \mathrm{AgCl}(3 \mathrm{M} \mathrm{KCl})$. 

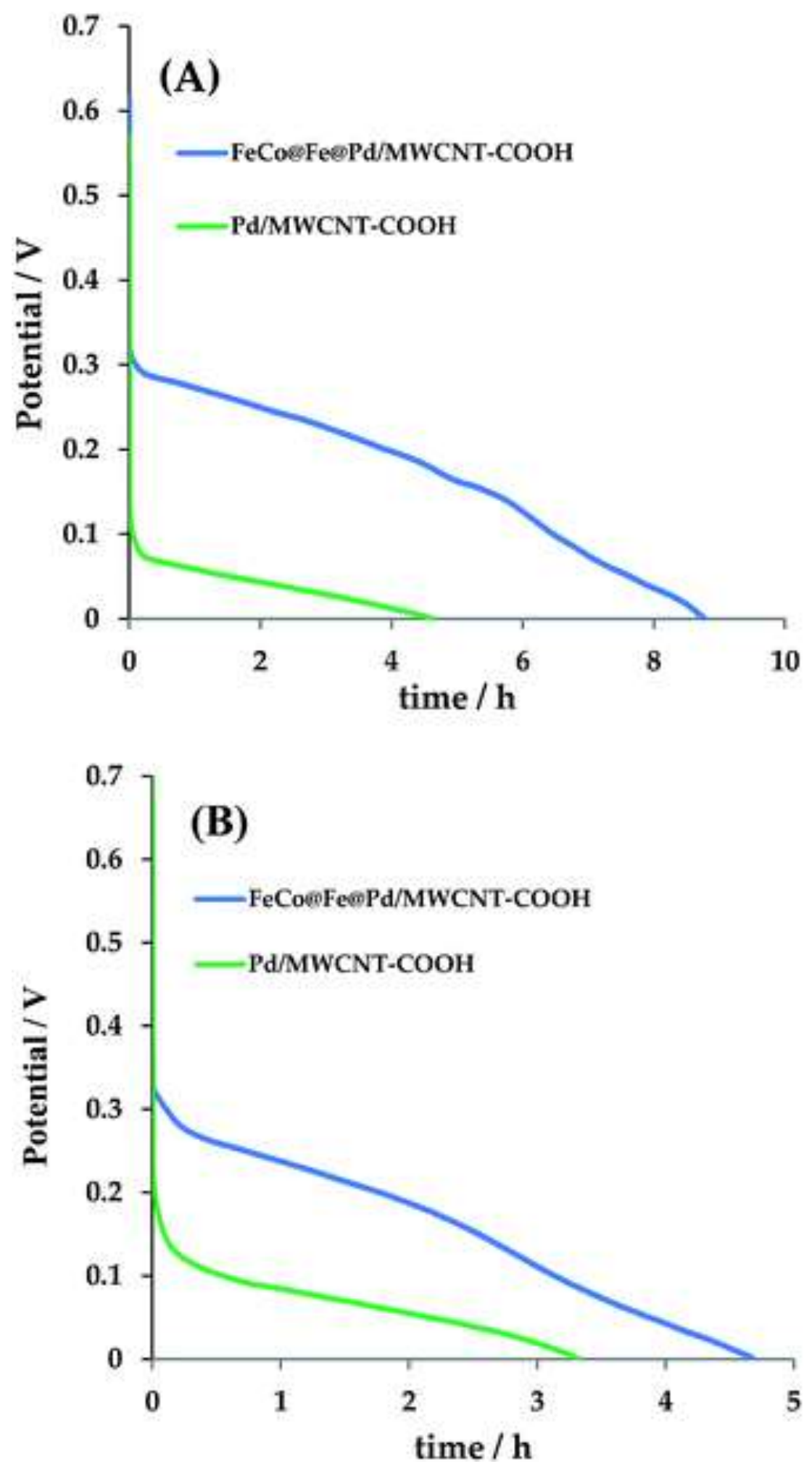

Fig. 8 Galvanostatic tests for passive AEM-DEGFC (A) and AEM-DGFC (B) with FeCo@Fe@Pd/MWCNT-COOH and Pd/MWCNT-COOH anodes and fuelled with $2 \mathrm{M} \mathrm{KOH}$ and 5 wt\% EG or GLY $\left(\mathrm{T}_{\text {cell }}=15-18{ }^{\circ} \mathrm{C}\right)$ at constant current of $20 \mathrm{~mA} \mathrm{~cm}^{-2}$. 


\section{Real-time alkaline direct alcohol fuel cell performance}

In view of the excellent performance of the MWCNT-COOH support for the Pd and FeCo@Fe@Pd nanoelectrocatalysts, the real-time fuel cell performance for alkaline direct EG and GLY fuel cells (DEGFC and DGFC) was investigated using the anionexchange membrane (AEM) Tokuyama A-201. The AEM-DEGFC and AEM-DGFC oxidation processes were investigated using passive oxygen-breathing direct alcohol fuel cells as described in the experimental section. Fig. 8 shows the galvanostatic curves for the AEM-DEGFC (Fig. 8A) and AEM-DGFC (Fig. 8B). For a reliable evaluation of the oxidation products, the anode compartment was sealed under a nitrogen atmosphere, while the cathode was exposed to air or oxygen with no significant variation in the cell performance. The fuel oxidation products were qualitatively and quantitatively determined by ${ }^{13} \mathrm{C}\left\{{ }^{1} \mathrm{H}\right\}$ NMR spectroscopy using appropriate calibration curves. Galvanostatic experiments were carried out at room temperature on the passive cells where the anode compartment was filled with $5 \mathrm{wt} \%$ of EG or GLY in $2 \mathrm{M} \mathrm{KOH}$ solution. After a conditioning time of $1 \mathrm{~h}$ at the OCV, the circuit of the cells was closed and a constant current of $102 \mathrm{~mA}\left(20 \mathrm{~mA} \mathrm{~cm}^{-2}\right)$ was allowed to flow until the cell voltage reached zero. The solution was not refuelled during the experiment since the aim was simply to establish the oxidation products and their selectivity.

The oxidation products of the two polyhydric alcohols were established using the ${ }^{13} \mathrm{C}\left\{{ }^{1} \mathrm{H}\right\}$ NMR spectroscopy. Fig. 9 shows typical ${ }^{13} \mathrm{C}\left\{{ }^{1} \mathrm{H}\right\}$ NMR spectra of the oxidation products of glycerol, (also see ESI, Fig. S5 $\dagger$ for the ${ }^{13} \mathrm{C}\left\{{ }^{1} \mathrm{H}\right\}$ NMR spectra for the oxidation of ethylene glycol). 


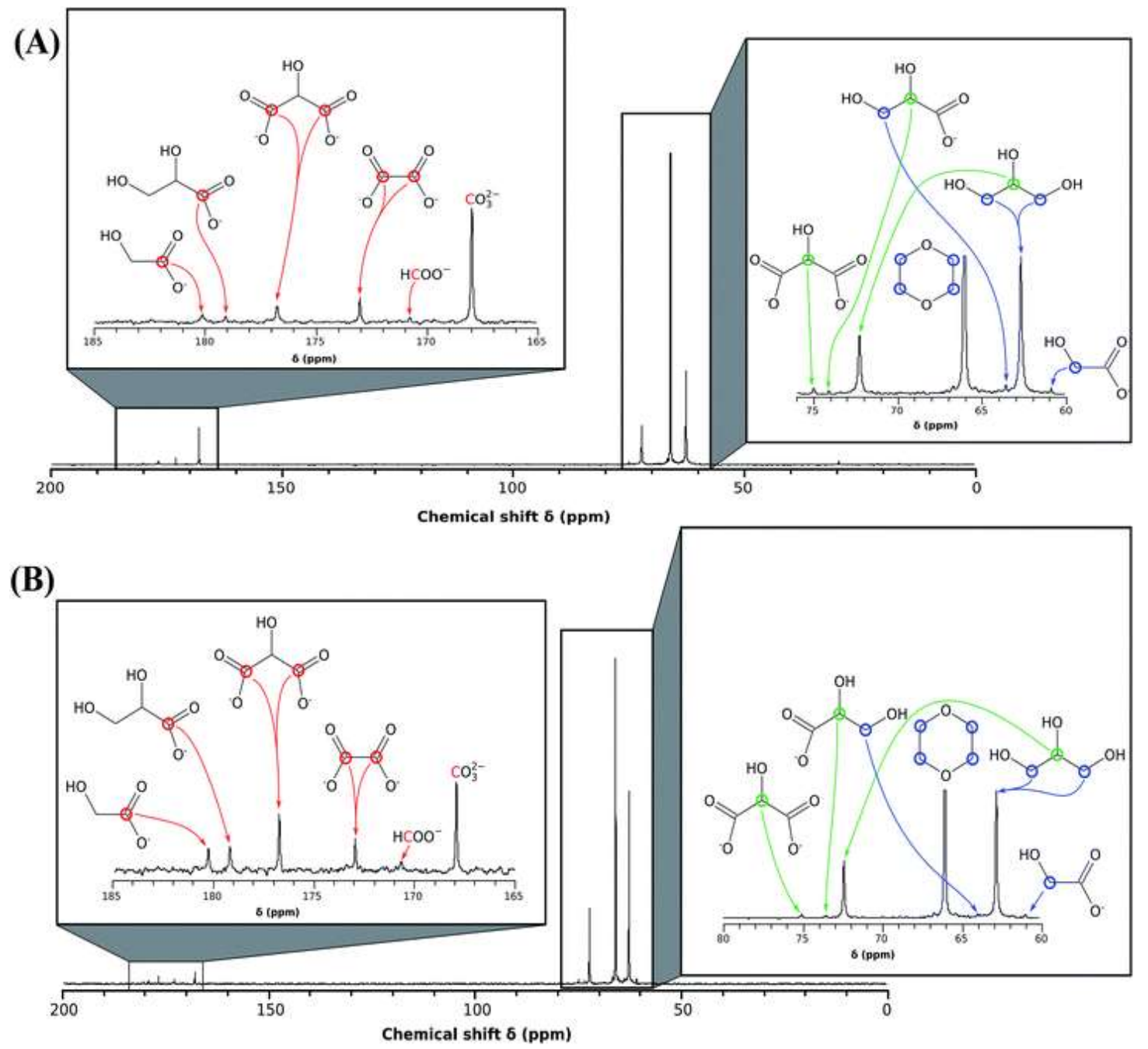

Fig. 9 NMR spectra of the oxidation products of glycerol at (A) FeCo@ $\mathrm{Fe} @ \mathrm{Pd} / \mathrm{MWCNT}-\mathrm{COOH}$ and (B) $\mathrm{Pd} / \mathrm{MWCNT}-\mathrm{COOH}$, Insets are the expanded portions of the main product peaks.

Fig. 10 represents the distribution of the exhaust products for the oxidation of EG (Fig. 10A) and GLY (Fig. 10B) at FeCo@Fe@Pd/MWCNT-COOH and Pd/MWCNT-COOH. The products of the oxidation of EG were the same using both FeCo@Fe@Pd/MWCNT$\mathrm{COOH}$ and $\mathrm{Pd} / \mathrm{MWCNT}-\mathrm{COOH}$ catalysts as anode catalysts. However, the selectivity of each oxidation product is different. For the DEGFC (Fig. 10A), the FeCo@Fe@Pd/MWCNT-COOH delivered 102 mA current for 8.7 h (Fig. 8A) yielding carbonate $(67 \%)$, formate $(2 \%)$, oxalate $(4 \%)$ and glycolate $(28 \%)$ with a fuel conversion of $65 \%$ and released energy of $551 \mathrm{~J}$. On the other hand, with the Pd/MWCNT-COOH as the anode catalyst for the DEGFC, the same of amount of current (102 mA) was delivered for $4.62 \mathrm{~h}$ yielding carbonate $(26 \%)$, formate $(4 \%)$, oxalate $(5 \%)$, and glycolate $(65 \%)$ with a conversion of $29 \%$ and cell energy of $67 \mathrm{~J}$. These reaction products have also been observed by other authors for the oxidation of EG in alkaline media ${ }^{25,55,56}$ who attributed them to the tolerance of the catalysts to poisoning as well as the ability of the catalysts to facilitate the $\mathrm{C}-\mathrm{C}$ bond cleavage. The two catalysts used in this AEMDEGFC study have a high tolerance to the presence of poisonous carbonaceous products 


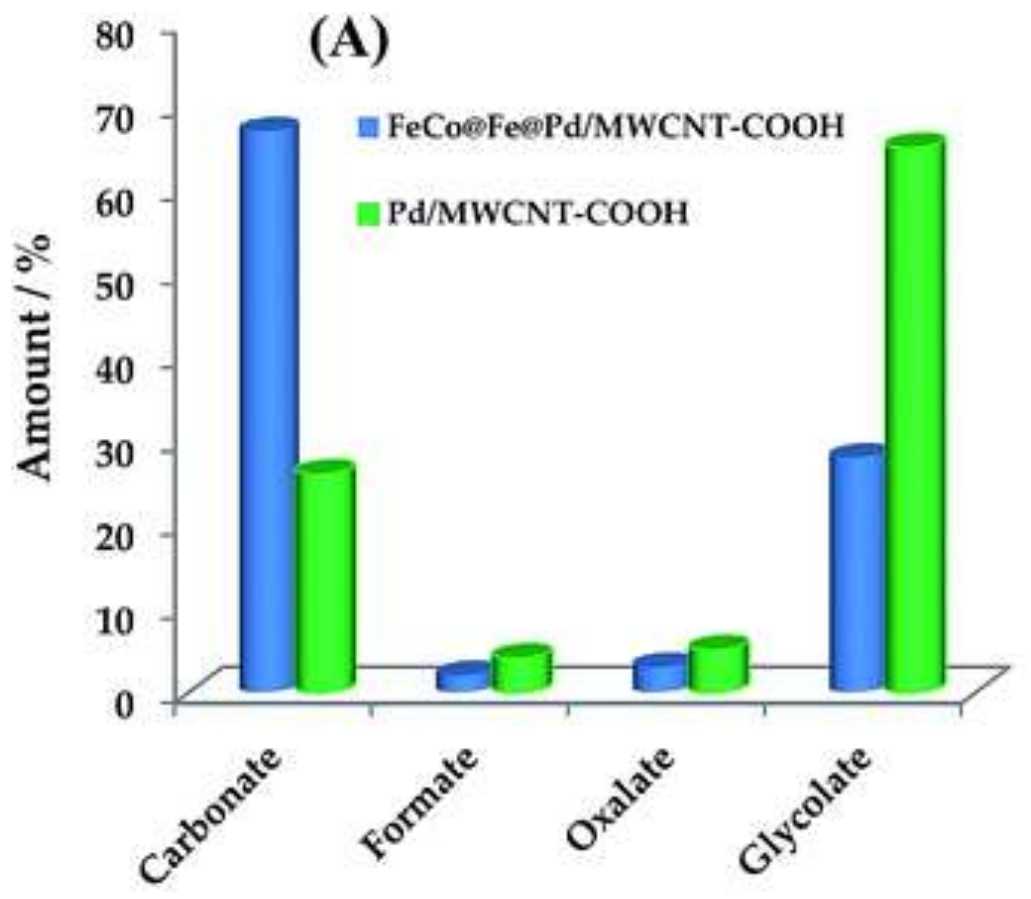

Oxidation Product

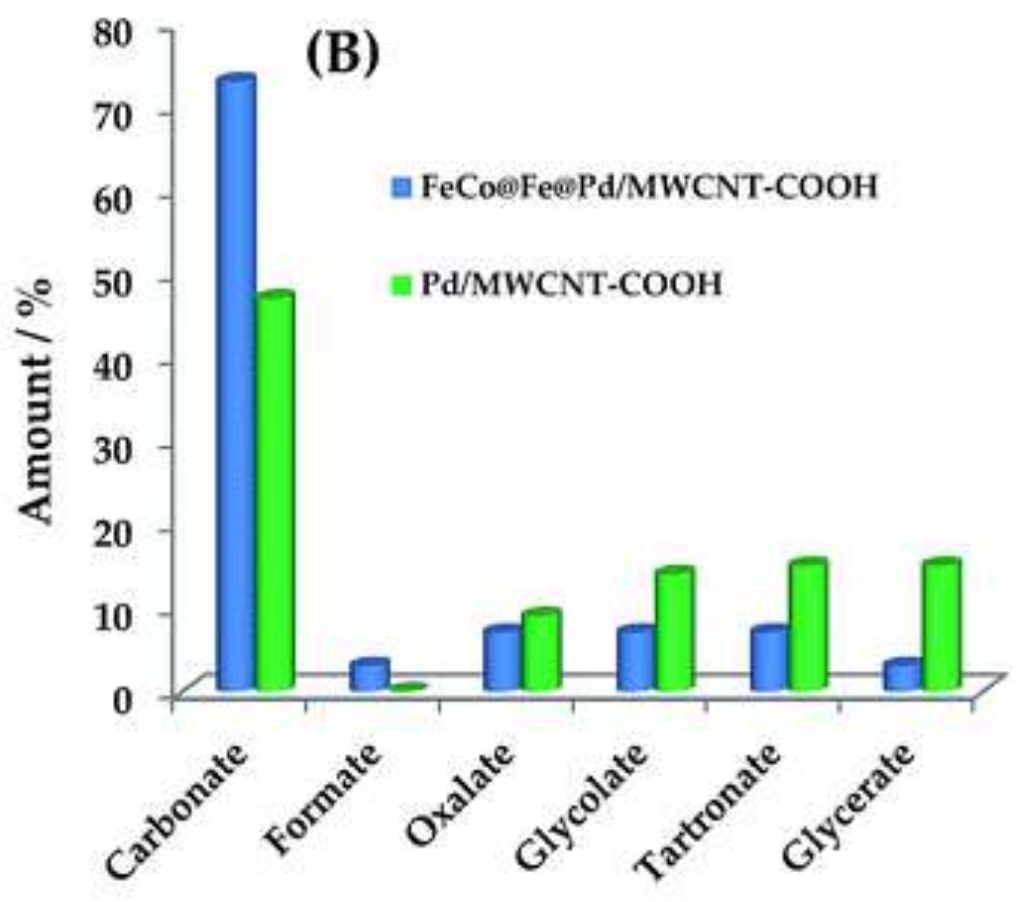

Oxidation Product

Fig. 10 Distribution of the exhaust products for (A) EG and (B) GLY oxidation at FeCo@Fe@Pd/MWCNT-COOH and Pd/MWCNT-COOH. 5\% alcohol/2 M KOH. 
like formates. Thus, we can infer that the ability of the FeCo@Fe@Pd/MWCNT-COOH to efficiently break the $\mathrm{C}-\mathrm{C}$ bonds of the $\mathrm{EG}$ to the carbonates is due to the enhanced electronic properties of the $\mathrm{Pd}$ surface layer arising from the lattice strain caused by the FeCo@Fe alloy. Although the Pd/MWCNT-COOH catalyst was not as selective in the complete oxidation of EG, its reaction for EG oxidation resulted in a high production of glycolate (a very useful product for a broad range of industrial applications from pharmaceuticals to the textiles) under mild conditions. Notably, no traces of either glyoxaldehyde or hemicetal were detected in any stage of the galvanostatic experiments.

Based on both literature data, ${ }^{57}$ and observed oxidation products, a two-way reaction path for the EG electrooxidation has been proposed (Scheme 1). Both FeCo@Fe@Pd/MWCNT-COOH and Pd/MWCNT-COOH electrocatalysts showed a preference towards the oxidation of one hydroxyl group of EG (path a), whereas a small amount of oxalate seems to be produced mainly by the direct oxidation of EG (path b) rather from the further oxidation of the glycolate (path d). ${ }^{30}$ While the Pd/MWCNT$\mathrm{COOH}$ showed a weak ability towards the $\mathrm{C}-\mathrm{C}$ bond, the FeCo@Fe@Pd/MWCNT$\mathrm{COOH}$ seems very efficient in the further oxidation of EG producing formate and a large amount of carbonate (route c).

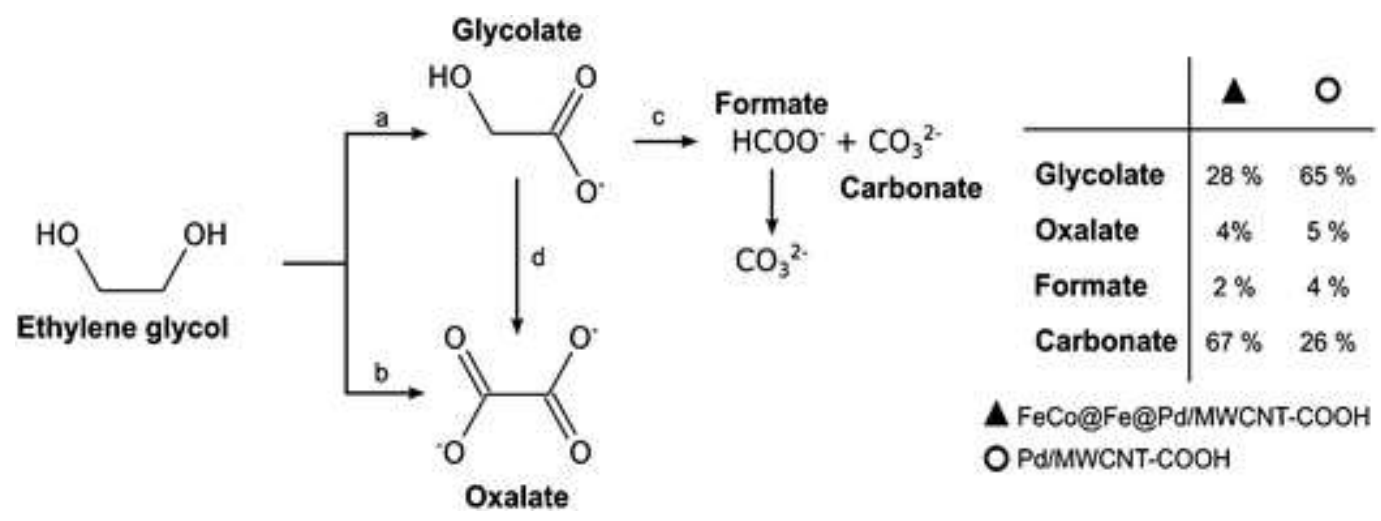

Scheme 1 Proposed reaction pathway for EG electro-oxidation on FeCo@Fe@Pd/MWCNT-COOH and $\mathrm{Pd} / \mathrm{MWCNT}-\mathrm{COOH}$.

The oxidation of GLY gave a plethora of oxidation products as shown in Fig. 10B based on the NMR exhaust product distribution analysis (Fig. 9). The FeCo@Fe@Pd/MWCNT-COOH delivered 102 mA current for 4.68 h yielding carbonate $(73 \%)$, formate $(3 \%)$, oxalate $(7 \%)$, glycerate $(3 \%)$, glycolate $(7 \%)$, tartonate $(7 \%)$ with a fuel conversion of $16 \%$ and released energy of $265 \mathrm{~J}$. However, with the Pd/MWCNT$\mathrm{COOH}$ as the anode catalyst, the same of amount of current $(102 \mathrm{~mA})$ was delivered for $3.32 \mathrm{~h}$ yielding carbonate $(47 \%)$, oxalate $(9 \%)$, tartonate $(15 \%)$, glycerate $(14 \%)$ and glycolate $(14 \%)$ with a conversion of $15 \%$ and released energy of $82 \mathrm{~J}$. No traces of secondary alcohol oxidation, such as dihydroxyacetone, hydroxypyruvate or mesoxalate were observed (Scheme 2). GLY is first oxidized to glyceraldehyde, which in turn is quickly oxidized to glycerate. Glycerate is further oxidized to tartronate (path c) and, by cleavage of $\mathrm{C}-\mathrm{C}$ bond, into glycolate and formate (path $\mathrm{d}$ ). The latter species leads to carbonate while the glycolate is oxidized to oxalate (path f). GLY is also oxidized 
directly to tartronate (path b). $\mathrm{CO}_{2}$ is prevalently a by-product of the oxidation of either glycerate or glycolate (path d and e) ${ }^{57}$ However, the oxidation of GLY yields significant amounts of carbonate. Furthermore, FeCo@Fe@Pd/MWCNT-COOH showed a higher released energy than $\mathrm{Pd} / \mathrm{MWCNT}-\mathrm{COOH}$ (about three times).

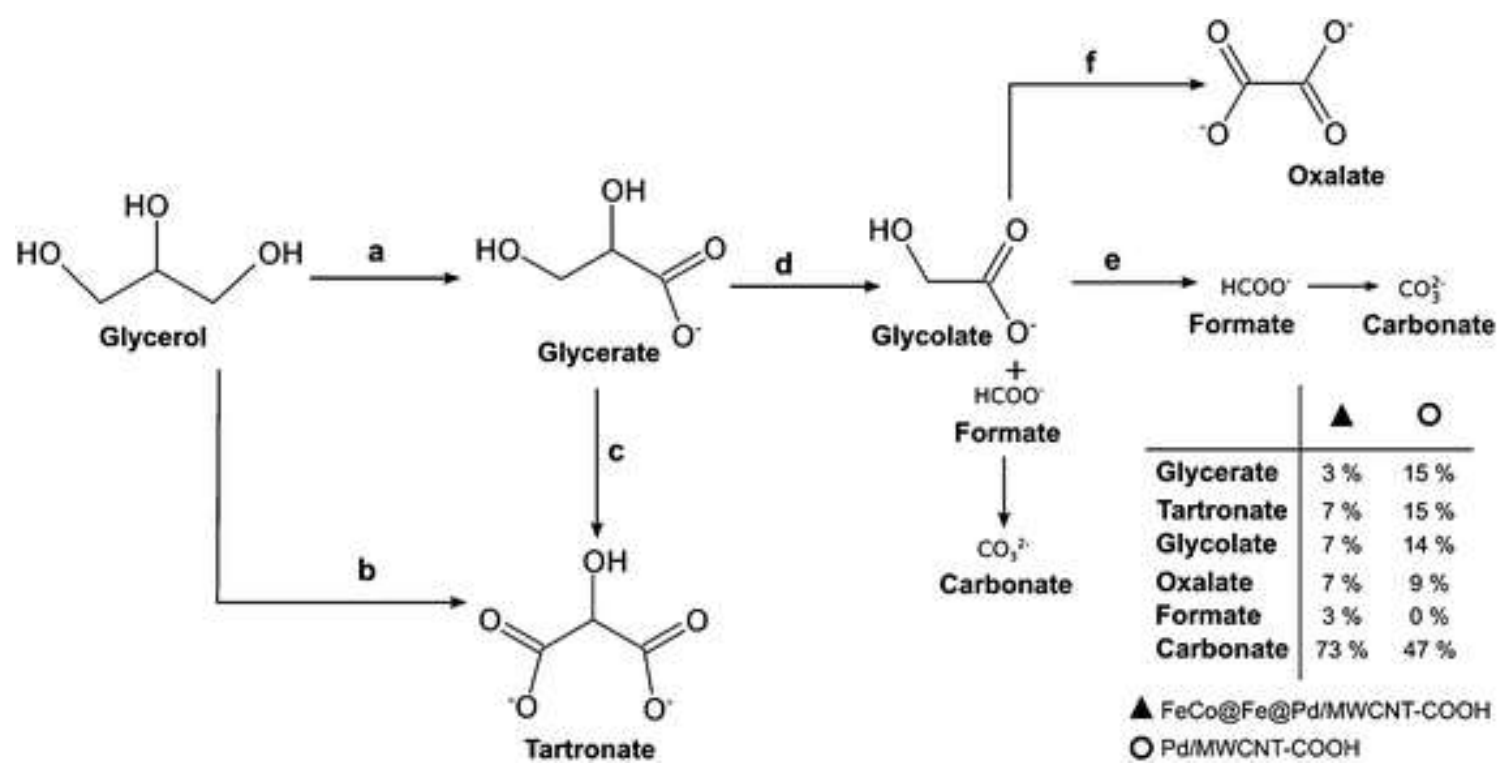

Scheme 2 Proposed reaction pathway for GLY electro-oxidation on FeCo@Fe@Pd/MWCNT-COOH and $\mathrm{Pd} / \mathrm{MWCNT}-\mathrm{COOH}$.

The experimental data clearly proves that both Pd-based catalysts on MWCNT supports, notably the FeCo@Fe@Pd/MWCNT-COOH, are able to dissociate GLY into fragments containing a single carbon at a high percentage under mild experimental conditions. The generation of carbonates as the main oxidation products suggests the unique ability of the catalysts to facilitate complete electro-oxidation of glycerol with an improved Faradaic efficiency. This result is very unique considering that quite a number of recently reported Pd-based catalysts (such as $\mathrm{Pd} / \mathrm{C},{ }^{58} \mathrm{PdNi} / \mathrm{C},{ }^{58} \mathrm{PdAu} / \mathrm{C},{ }^{58} \mathrm{PdRh} / \mathrm{C},{ }^{31} \mathrm{PdAu} / \mathrm{C}$ and $\mathrm{PdNi}{ }^{59}$ and $\mathrm{PdPtBi} / \mathrm{C}^{60}$ ) did not show any selectivity towards the complete oxidation of GLY.

\section{Conclusions}

This work studied the behaviour of a Pd-based ternary core-shell nanoparticles (FeCo@Fe@Pd) supported on MWCNT-COOH and MWCNT-SO 3 H for the electrocatalytic oxidation of EG and GLY in alkaline media. We clearly proved that the surface functional groups (mainly $-\mathrm{COOH}$ and $-\mathrm{SO}_{3} \mathrm{H}$ ) on the MWCNT support played a critical role on the physico-chemical properties of the FeCo@Fe@Pd nanocatalyst towards the electrocatalytic oxidation of EG and GLY.The FeCo@Fe@Pd/MWCN$\mathrm{COOH}$ was characterized by smaller nanoparticles, more uniform loading on the support, large electrochemically-active surface area and enhanced electrocatalytic activity compared to its $\mathrm{FeCo} @ \mathrm{Fe} @ \mathrm{Pd} / \mathrm{MWCNT}-\mathrm{SO}_{3} \mathrm{H}$ counterparts. When the FeCo@Fe@Pd/MWCNT-COOH was used for a preliminary study in passive airbreathing anion-exchange membrane based fuel cells (AEM-DEGFC and AEM-DGFC), 
the exhaust products revealed high levels of selectivity towards the complete oxidation of EG and GLY under benign experimental conditions. The high catalytic performance of the FeCo@Fe@Pd/MWCNT-COOH has been interpreted as the results of its improved electronic properties coupled with the high affinity of its $-\mathrm{COOH}$ surface with the catalyst species. The study has indeed opened doors for future developments of these Pdbased nanocatalysts, such as the exploration of more nanocarbon platforms, optimization of the catalyst system for improved oxidation and selectivity of alcohols, and application in active ADAFCs for enhanced power and energy densities.

\section{Acknowledgements}

This work was funded by the CSIR, the University of Pretoria as well as the South Africa's Department of Science and Technology (DST) and National Research Foundation (NRF) under the "Nanotechnology Flagship Programme" (supercapacitors and fuel cell project, Grant no. 69849). OOF thanks the DST/NRF for doctoral bursary under this project.

\section{Notes and references}

1. D. Morales-Acosta, L. G. Arriaga, L. Alvarez-Contreras, S. F. Luna and F. J. R. Varela, Electrochem. Commun., 2009, 11, 1414-1417

2. R. Chetty and K. Scott, J. Appl. Electrochem., 2007, 37, 1077-1084

3. V. Livshits, M. Philosoph and E. Peled, J. Power Sources, 2008, 178, 687-691

4. D. Kaplan, L. Burstein, Y. Rosenberg and E. Peled, J. Power Sources, 2011, 196, 8286-8292

5. D. Kaplan, M. Alon, L. Burstein, Y. Rosenberg and E. Peled, J. Power Sources, 2011, 196, 1078-1083

6. A. Serov and C. Kwak, Appl. Catal., B, 2010, 97, 1-12

7. N. Ji, T. Zhang, M. Zheng, A. Wang, H. Wang, X. Wang and J. G. Chen, Angew. Chem., Int. Ed., 2008, 47, 8510-8513

8. M.-Y. Zheng, A.-Q. Wang, N. Ji, J.-F. Pang, X.-D. Wang and T. Zhang, ChemSusChem, 2010, 3, 63-66

9. L. Xin, Z. Zhang, Z. Wang and W. Li, ChemCatChem, 2012, 4, 1105-1114

10. Z. Zhang, L. Xin and W. Li, Appl. Catal., B, 2012, 119-120, 40-48

11. J. V. Gerpen, Fuel Process. Technol., 2005, 86, 1097-1107

12. T. J. Schmidt, H. A. Gasteiger and R. J. Behm, J. Electrochem. Soc., 1999, 146, 1296-1304

13. V. Mazmuder, M. Chi, M. N. Mankin, Y. Liu, O. Metin and D. A. Sun, Nano Lett., 2012, 12, 1102-1106

14. Y. W. Lee, M. Kim, Y. Kim, S. W. Kang, J. H. Lee and S. W. Han, J. Phys. Chem. C, 2010, 114, 7689-7693

15. C. Zhu, S. Guo and S. Dong, J. Mater. Chem., 2012, 22, 14851-14855

16. R. M. Modibedi, K. I. Ozoemena and M. K. Mathe, Palladium-Based Nanocatalysts for Alcohol Electro-oxidation in Alkaline Media in, Electrocatalysis in Fuel Cells, Lecture Notes in Energy 9, ed. M. Shao, SpringerVerlag, London, 2013, ch. 6, pp. 129-156 
17. S. Rousseau, C. Coutanceau and C. Lamy, J. Power Sources, 2006, 158, 18-24

18. Z.-P. Sun, X.-G. Zhang, R.-L. Liu, Y.-Y. Liang and H.-L. Li, J. Power Sources, 2008, 185, 801-806

19. P. K. Shen and C. Xu, Electrochem. Commun., 2006, 8, 184-188

20. Y. Wang, T. S. Nguyen, X. Liu and X. Wang, J. Power Sources, 2010, 195, 26192622

21. R. K. Pandey and V. Lakshminarayanan, J. Phys. Chem. C, 2009, 113, 2159621603

22. S. Cherevko, X. Xing and C.-H. Chung, Electrochim. Acta, 2011, 56, 5771-5775

23. F. Ksar, L. Ramos, B. Keita, L. Nadjo, P. Beaunier and H. Remita, Chem. Mater., 2009, 21, 3677-3683

24. K. Ishiyama, F. Kosaka, I. Shimada, Y. Oshima and J. Otomo, J. Power Sources, 2013, 225, 141-149

25. K. Miyazaki, T. Matsumiya, T. Abe, H. Kurata, T. Fukutsuka, K. Kojima and Z. Ogumi, Electrochim. Acta, 2011, 56, 7610-7614

26. P. S. Fernández, M. E. Martins and G. A. Camara, Electrochim. Acta, 2012, 66, $180-187$

27. J. F. Gomes, F. B. C. Paula and L. H. S. Gasparotto, Electrochim. Acta, 2012, 76, 88-93

28. D. Z. Jeffery and G. A. Camara, Electrochem. Commun., 2010, 12, 1129-1132

29. C. Bianchini and P. K. Shen, Chem. Rev., 2009, 109, 4183-4206

30. V. Bambagioni, M. Bevilacqua, C. Bianchini, J. Filippi, A. Marchionni, F. Vizza, L. Q. Wang and P. K. Shen, Fuel Cells, 2010, 10, 582-590

31. R. S. Ferreira Jr, M. Janete Giz and G. A. Camara, J. Electroanal. Chem., 2013, 697, 15-20

32. L. An, T. S. Zhao, S. Y. Shen, Q. X. Wu and R. Chen, Int. J. Hydrogen Energy, 2010, 35, 4329-4335

33. O. O. Fashedemi, B. Jules and K. I. Ozoemena, Chem. Commun., 2013, 49, 2034-2036

34. O. O. Fashedemi and K. I. Ozoemena, Phys. Chem. Chem. Phys., 2013, 15, 20982-20991

35. O. O. Fashedemi and K. I. Ozoemena, Electrochim. Acta, 2014, 128, 279-286

36. J. A. Liu, G. Rinzler, H. Dai, J. H. Hanfer, R. K. Bradley, P. J. Boul, A. Lu, T. Iverson, K. Shelimov, C. B. Huffman, F. R. Macias, Y. S. Shon, T. R. Lee and D. T. Colbert, Science, 1998, 280, 1253

37. Z. Sun, X. Zhang, Y. Liang and H. Li, J. Power Sources, 2009, 191, 366-370

38. T. Ramulifho, K. I. Ozoemena, R. M. Modibedi, C. J. Jafta and M. K. Mathe, Electrochim. Acta, 2012, 59, 310-320

39. V. Bambagioni, C. Bianchini, J. Filippi, A. Lavacchi, W. Oberhauser, A. Marchionni, S. Moneti, F. Vizza, R. Psaro, V. Dal Santo, A. Gallo, S. Recchia and L. Sordelli, J. Power Sources, 2011, 196, 2519-2529

40. V. Bambagioni, C. Bianchini, A. Marchionni, J. Filippi, F. Vizza, J. Teddy, P. Serp and M. Zhiani, J. Power Sources, 2009, 190, 241-251

41. D. Wang, H. L. Xin, Y. Yu, H. Wang, E. Rus, D. A. Muller and H. D. Abruna, J. Am. Chem. Soc., 2010, 132, 17664-17666 
42. V. Mazumder, M. Chi, K. L. More and S. Sun, J. Am. Chem. Soc., 2010, 132, 7848-7849

43. T. Ramulifho, K. I. Ozoemena, R. M. Modibedi, C. J. Jafta and M. K. Mathe, J. Electroanal. Chem., 2013, 692, 26-30

44. Y. Wang, X. P. Gao, Z. W. Lu, W. K. Hu, Z. Zhou, J. Q. Qu and P. W. Shen, Electrochim. Acta, 2005, 50, 2187-2191

45. S. Kim and S.-J. Park, J. Power Sources, 2006, 159, 42-45

46. R. Li, H. Mao, J. Zhang, T. Huang and A. Yu, J. Power Sources, 2013, 241, 660667

47. X. Yang, Q. Yang, J. Xu and C.-S. Lee, J. Mater. Chem., 2012, 22, 8057

48. Y. Suo, L. Zhuang and J. Lu, Angew. Chem., Int. Ed., 2007, 46, 2862-2864

49. D. A. J. Rand and R. Woods, J. Electroanal. Chem., 1971, 31, 29-38

50. B. Wu, B. Wang, C. Deng and Y. Gao, Appl. Catal., B, 2011, 103, 163-168

51. Y.-W. Lee, A.-R. Ko, S.-B. Han, H.-S. Kim and K.-W. Park, Phys. Chem. Chem. Phys., 2011, 13, 5569-5572

52. Z. X. Liang, T. S. Zhao, J. B. Xu and L. D. Zhu, Electrochim. Acta, 2009, 54, 2203-2208

53. C. Bianchini, V. Bambagioni, J. Filippi, A. Marchionni, F. Vizza, P. Bert and A. Tampucci, Electrochem. Commun., 2009, 11, 1077-1080

54. Y. Jiang, Y. Lu, F. Li, T. Wu, L. Niu and L. W. Chen, Electrochem. Commun., 2012, 19, 21-24

55. R. B. de Lima, V. Paganin, T. Iwasita and W. Vielstich, Electrochim. Acta, 2003, 49, 85-91

56. L. Wang, H. Meng, P. K. Shen, C. Bianchini, F. Vizza and Z. Wei, Phys. Chem. Chem. Phys., 2011, 13, 2667-2673

57. A. Marchionni, M. Bevilacqua, C. Bianchini, Y.-X. Chen, J. Filippi, P.

Fornasiero, A. Lavacchi, H. Miller, L. Wang and F. Vizza, ChemSusChem, 2013, 6, 518-528

58. A. Villa, M. Plebani, M. Schiavoni, C. Milone, E. Piperopoulos, S. Galvagno and L. Prati, Catal. Today, 2012, 186, 76-82

59. M. Simões, S. Baranton and C. Coutanceau, Appl. Catal., B, 2010, 93, 354-362

60. M. Simões, S. Baranton and C. Coutanceau, Appl. Catal., B, 2011, 110, 40-49 


\section{Electronic Supporting Information}

The main objective of the study is to use literature-established techniques to functionalise MWCNTs with $-\mathrm{COOH}$ or $-\mathrm{SO}_{3} \mathrm{H}$ and subsequently use them as support for the Pd-based core-shell catalysts. FTIR and Raman were used to confirm the successful functionalization of the MWCNTs a with $-\mathrm{COOH}$ or $-\mathrm{SO}_{3} \mathrm{H}$ functional groups. The concentrations of the $\mathrm{COOH}$ or $-\mathrm{SO}_{3} \mathrm{H}$ were not determined, but it is known that for MWCNTs, the concentric arrangement of the graphene layers does not allow for the attainment of the surface atomic oxygen percentages higher than $7-8 \%{ }^{1}$

Figures S1 compares the FTIR spectra of MWCNT-COOH (Fig. S1A) and MWCNT-SO 3 H (Fig. S1B). The MWCNT-COOH showed intense band at $3428 \mathrm{~cm}^{-1}$ due to the stretching vibrational modes of the $\mathrm{O}-\mathrm{H}$ group, very weak bands at $\sim 2888$ and $\sim 2333 \mathrm{~cm}^{-1}$ due to symmetric and asymmetric C-H of aryl groups. The bands at 1719 and $1587 \mathrm{~cm}^{-1}$ are due to the $\mathrm{C}=\mathrm{O}$ stretching vibrations from carboxylic and carbonyl groups. The strong band at $1225 \mathrm{~cm}^{-1}$ is $\mathrm{O}-\mathrm{H}$ bending deformation in $-\mathrm{COOH}$. The peak at $1056 \mathrm{~cm}^{-1}$ is assigned to $\mathrm{C}$ O stretching vibrations of epoxides, or cyclic ethers. Interestingly, upon sulphonation of the MWCNT-COOH, the intense bands due to the $\mathrm{OH}\left(3428 \mathrm{~cm}^{-1}\right)$ and $\mathrm{C}=\mathrm{O}\left(1719\right.$ and $1587 \mathrm{~cm}^{-}$ $\left.{ }^{1}\right)$ groups disappear leading to two strong bands at 1467 and $1380 \mathrm{~cm}^{-1}$ which are the characteristic absorption bands of organic sulfonate groups; the $\mathrm{O}=\mathrm{S}=\mathrm{O}$ asymmetric and $\mathrm{O}=\mathrm{S}=\mathrm{O}$ symmetric stretching motions respectively. The intense bands at 2980 and $2862 \mathrm{~cm}^{-1}$ are attributed to $\mathrm{C}-\mathrm{H}$ stretching motions of aromatic and unsaturated alkyl groups. The group of bands at $995,888,766 \mathrm{~cm}^{-1}$ are assigned to the $\mathrm{C}-\mathrm{O}$ stretching vibrations of substituted pyridines or aromatic rings. 

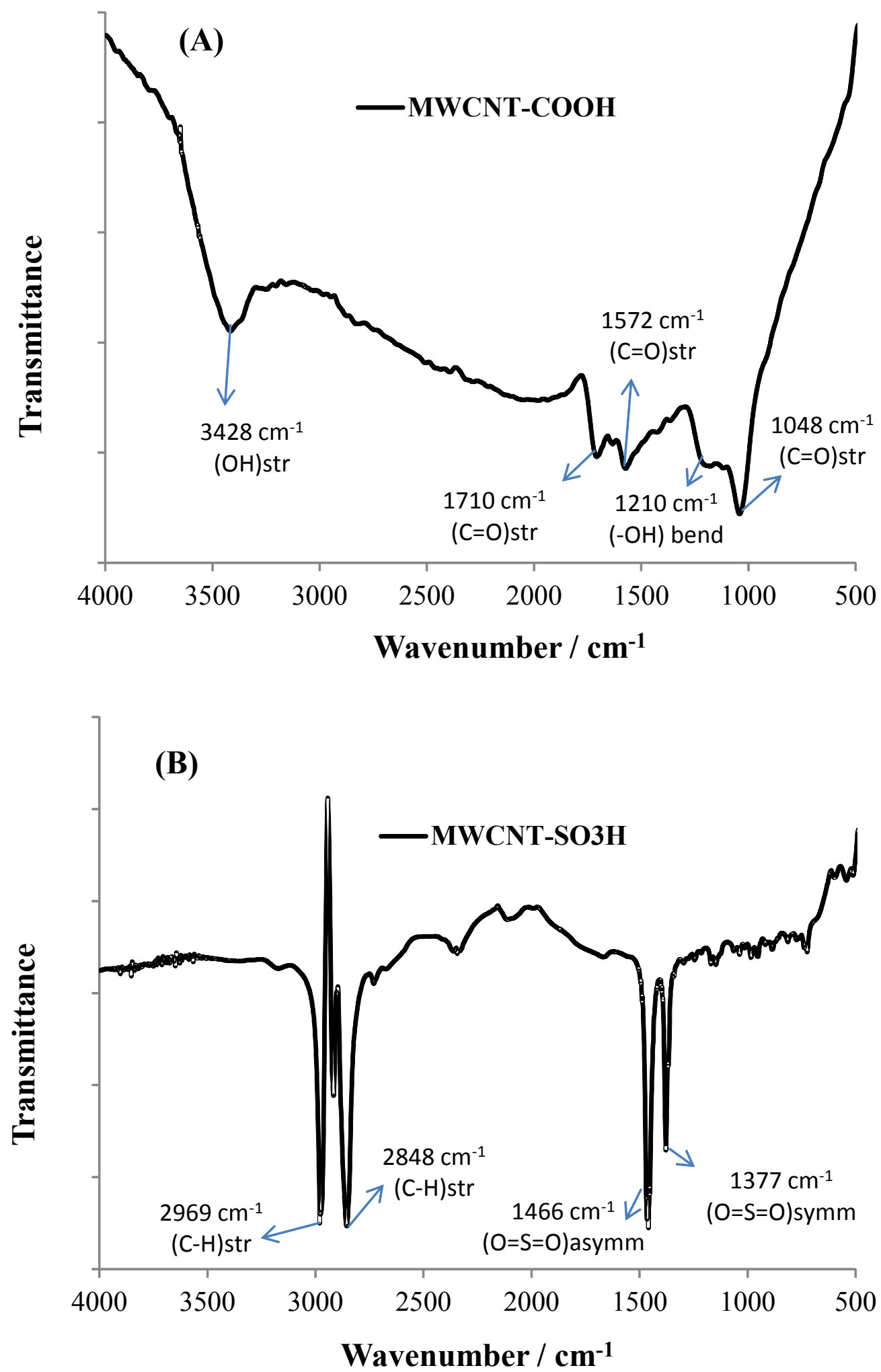

Figure S1: Comparative IR spectra of (A) MWCNT-COOH) and (B) MWCNT-SO 3 H. 


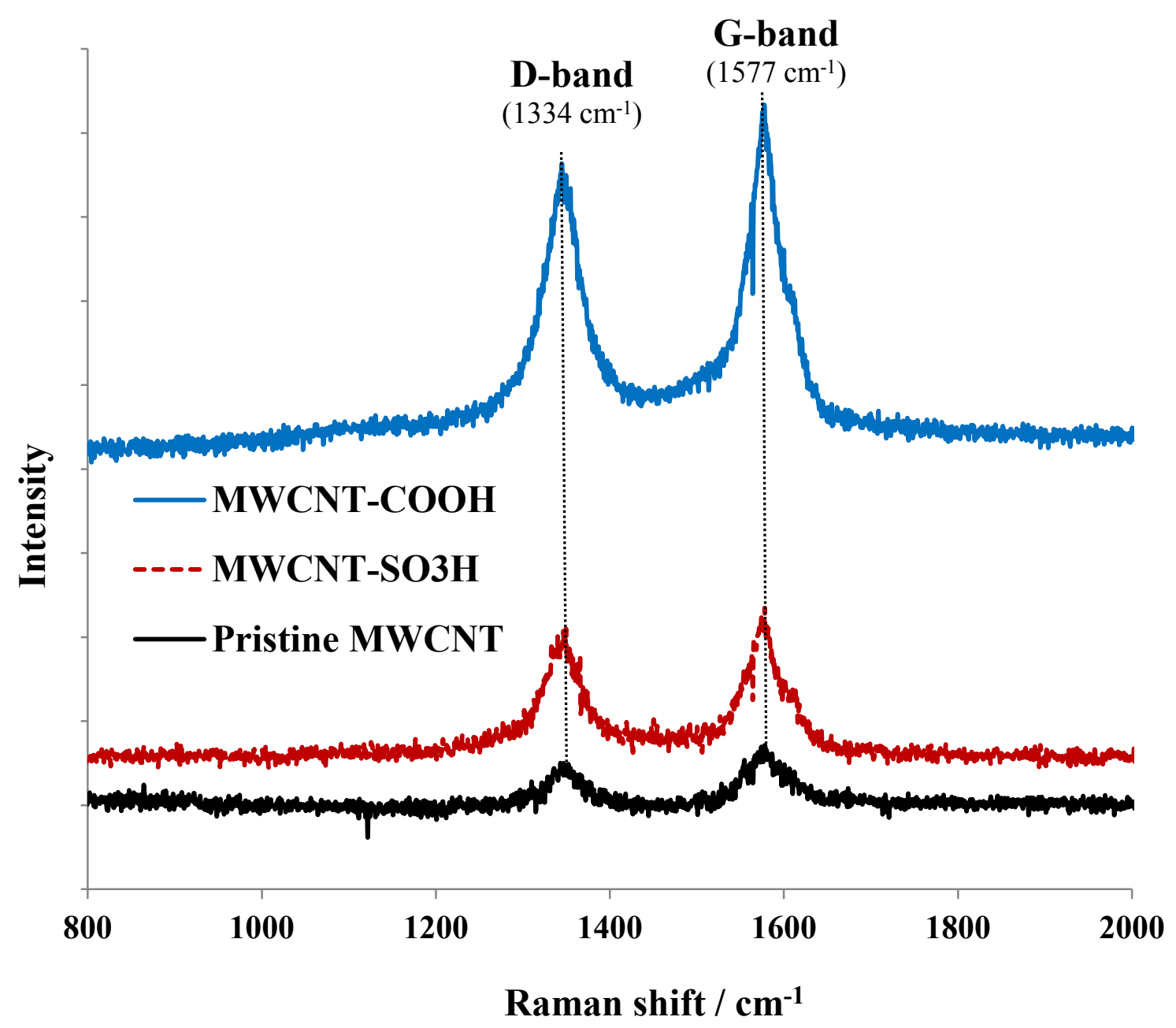

Figure S2: Raman spectra of Pristine MWCNT, carboxylate functionalised MWCNT (MWCNT-COOH) and sulfonate-functionalised MWCNTs (MWCNT-SO 3 H).

Figure S2 shows the Raman spectra of pristine MWCNT, MWCNT-COOH and MWCNT$\mathrm{SO}_{3} \mathrm{H}$. The D-band reflects the disorder in the MWCNT $\left(\mathrm{sp}^{3} \mathrm{C}\right)$, thus increase in the intensity of the D-band is an indication of the rise in the defect density (amount of defects) in the MWCNTs or a decrease in the structural order of the carbon nanotubes bundles. These defects arise from the added functional groups, missing carbon atoms in the walls of the carbon nanotubes or the inhomogeneous decoration of the tube wall by functional groups. 
From the Raman spectra, the D-bands appear at ca. $1344 \mathrm{~cm}^{-1}$, while the graphite structure of the MWCNTs, G-band $\left(\mathrm{sp}^{2} \mathrm{C}\right)$ appears at $c a .1577 \mathrm{~cm}^{-1}$. There is no noticeable change in positions of these G-bands for the pristine and functionalised MWCNTs, which means the electronic characteristics remain essentially intact after acid-functionalisation. The degree of functionalization or defects on the MWCNT walls is indicated by the intensity ratios of the D- and G-bands $\left(I_{\mathrm{D}} / I_{\mathrm{G}}\right)$. The $I_{\mathrm{D}} / I_{\mathrm{G}}$ values for the MWCNT-COOH, MWCNT-SO ${ }_{3} \mathrm{H}$ and pristine MWCNTs are $0.90 \pm 0.14,0.88 \pm 0.12$ and $0.72 \pm 0.10$, respectively, indicating that the degree of functionalization of MWCNT-COOH and MWCNT- $\mathrm{SO}_{3} \mathrm{H}$ is essentially the same.

As part pf the HRTEM, electron energy loss spectroscopy (EELS) was used to visualise the core-shell nature of the core alloy. There was a co-existence of pure iron and iron oxides; nonetheless there were clear contrasts between the inner FeCo alloy and the segregated $\mathrm{Fe} / \mathrm{Fe}_{\mathrm{x}} \mathrm{O}_{\mathrm{y}}$ shell around the edges of the core-shell, irrespective of the type of MWCNTs used as support.
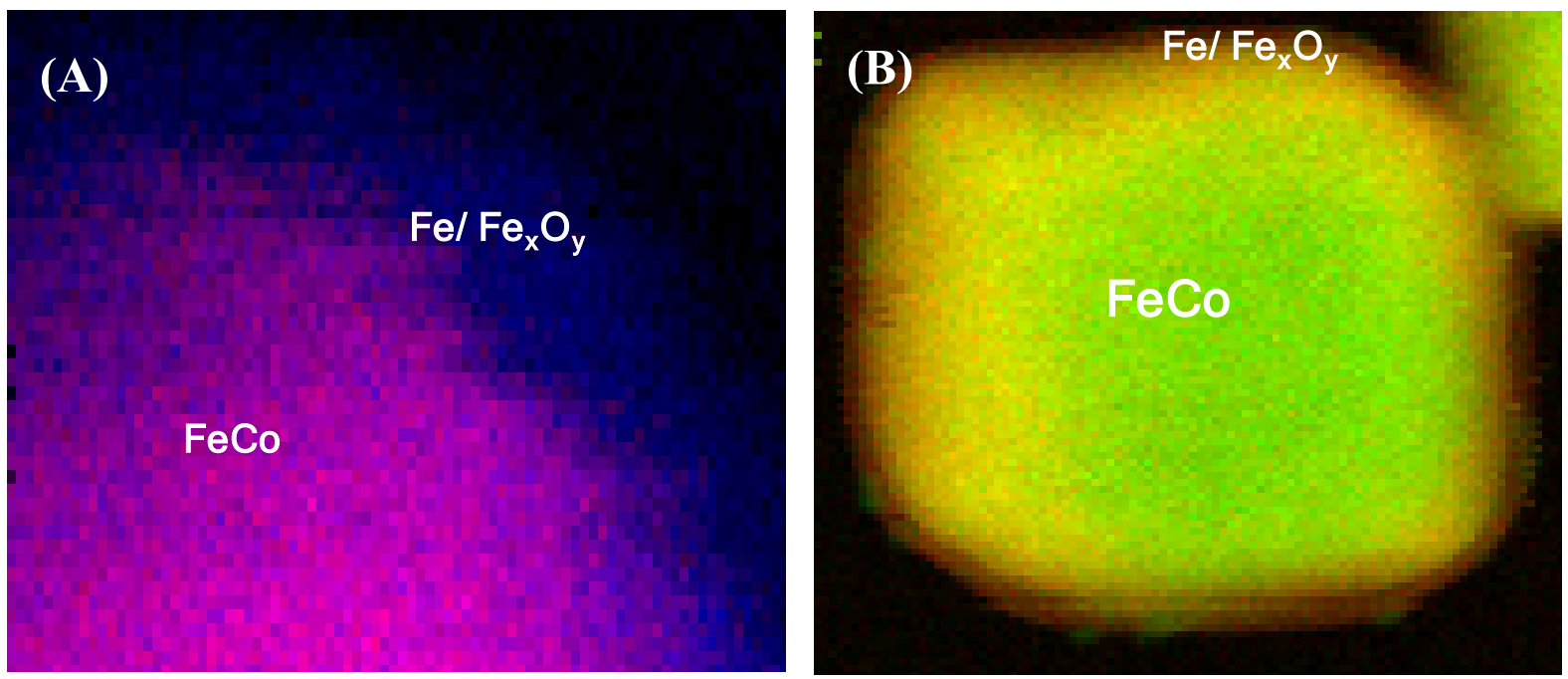

Figure S3: Electron energy loss spectral (EELS) images of FeCo@Fe/MWCNT-COOH (A) and $\mathrm{FeCo} @ \mathrm{Fe} / \mathrm{MWCNT}-\mathrm{SO}_{3} \mathrm{H}(\mathrm{B})$. 
To provide further insights into the existence of the surface oxide layer of Pd on the coreshell, XPS experiments were conducted. The Fe and Co signals were very weak and poorly resolved. The presence of the $\mathrm{PdO}$ species is in excellent agreement with other reports that $\mathrm{Pd}$ is easily oxidized to $\mathrm{PdO}$ in air. ${ }^{2-4}$

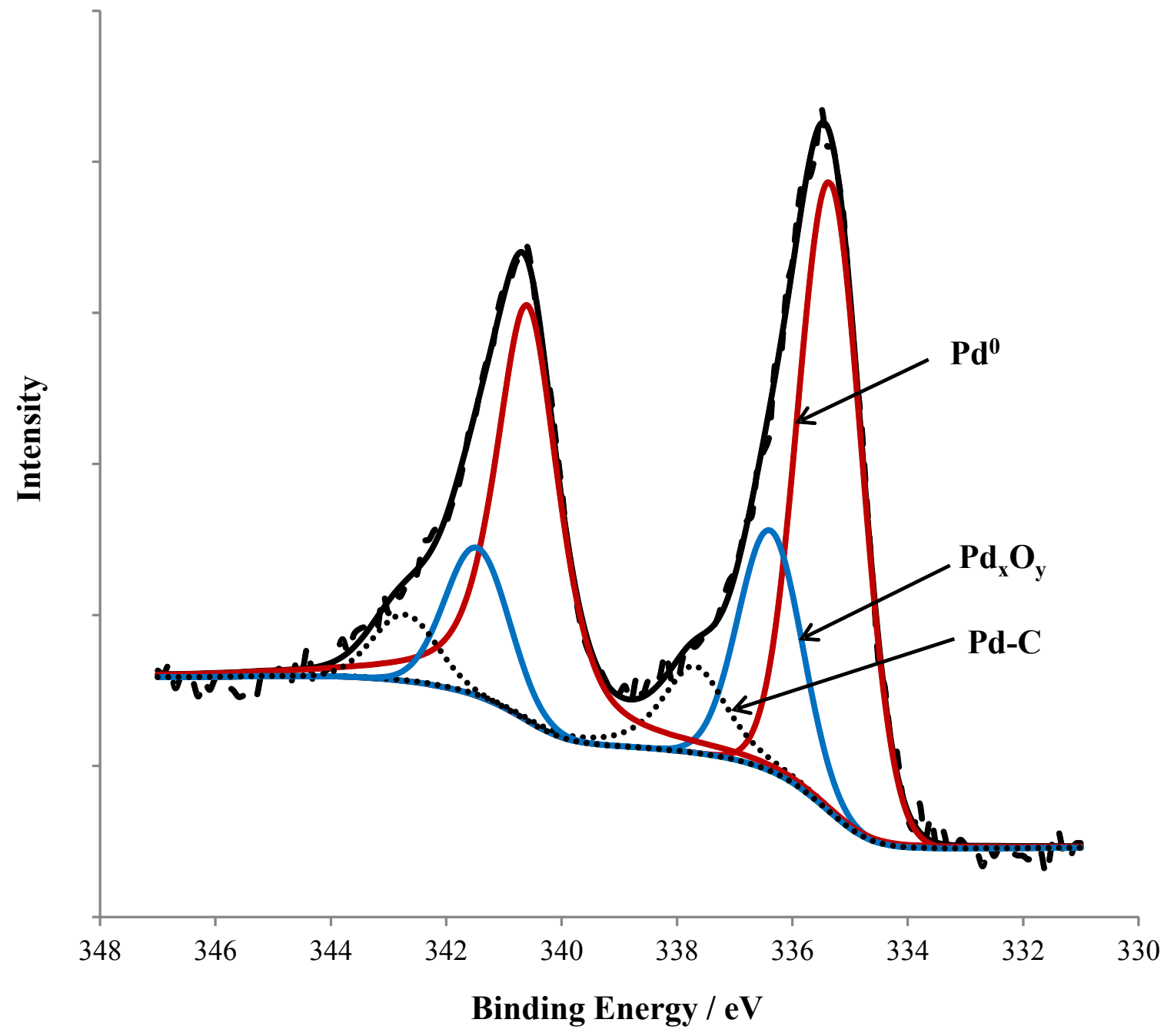

Figure S4: Typical XPS of FeCo@Fe@Pd/MWCNT-COOH. 
(A)

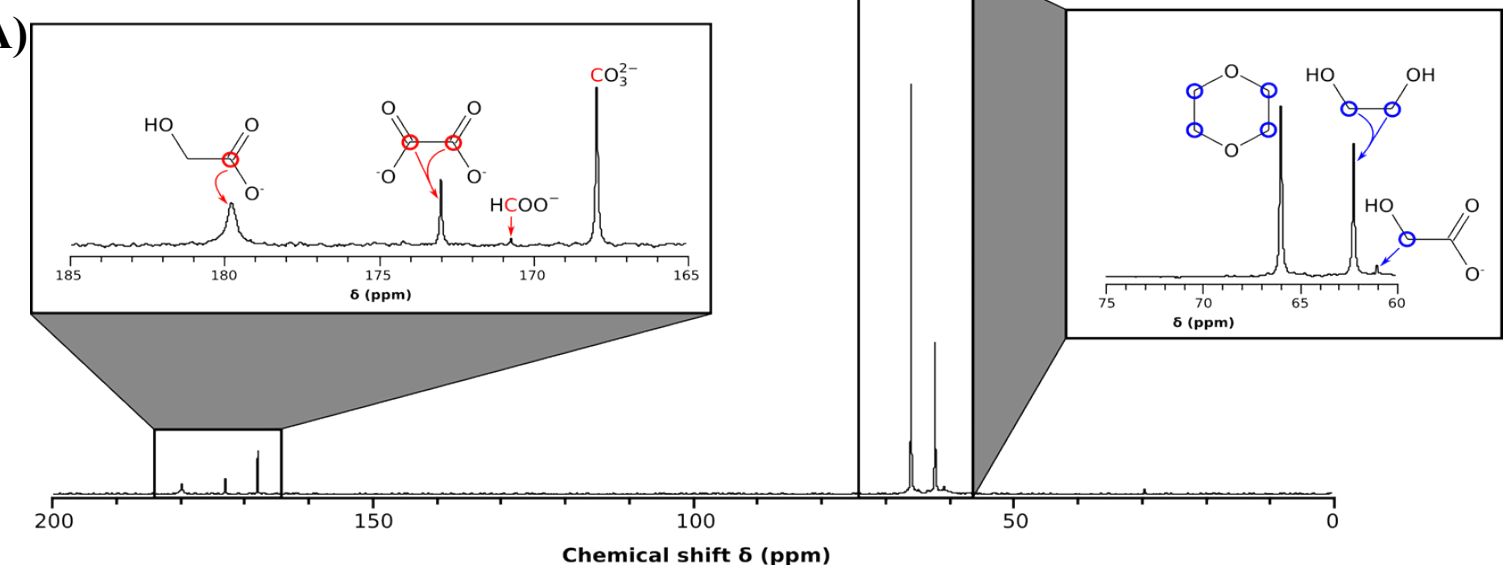

(B)

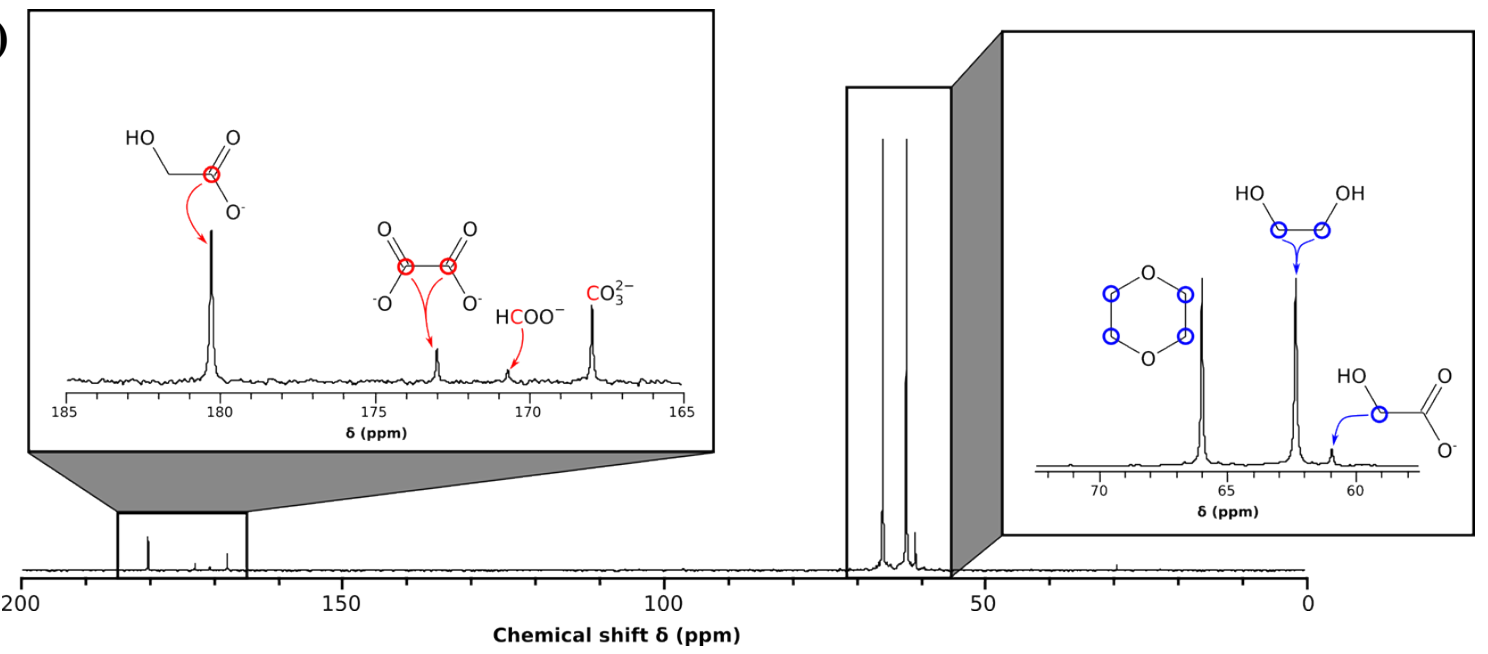

Figure S5: NMR spectra of the oxidation products of ethylene glycol at FeCo@Fe@Pd/MWCNT-COOH (A) and Pd/MWCNT-COOH (B), Insets are the expanded portions of the main product peaks.

\section{References}

1) R. Yudianti, H. Onggo, Sudirman, Y. Saito, T. Iwata, J-I. Azuma, The Open Materials Science Journal, 2011, 5, 242-247.

2) L. Wang, Z. Lou, R. Wang, T. Fei, T. Zhang, J. Mater. Chem. 2012, 22, 12453.

3) J. I. Han, S. J. Hong, Jpn. J. Appl. Phys. 2005, 44, 7698.

4) A. Kolmakov, S. Potluri, A. Barinov, T. O. Mentes, L. Gregoratti, M. A. Nino, A. Locatelli, M. Kiskinova, ACS Nano 2008, 2, 1993. 